\title{
Unlocking the Arctic's Resources Equitably: Using a Law-and-Science Approach to Fix the Beaufort Sea Boundary
}

\author{
Pieter Bekker \\ Chair in International Law, Centre for Energy, Petroleum and Mineral Law \\ and Policy, University of Dundee, United Kingdom \\ p.bekker@dundee.ac.uk
}

Robert van de Poll

Global Director Law of the Sea, Fugro, Canada

rvandepoll@fugro.com

\begin{abstract}
This article analyses the unresolved maritime boundary situated in Arctic waters in the Beaufort Sea, between Canada and the United States through an integrated law-and-science approach incorporating new imagery technology. Resolving the Canada-United States disagreement over the Beaufort Sea boundary based on modern geo-scientific technology and the three-step delimitation methodology developed in the jurisprudence of international courts and tribunals could serve as a catalyst for the peaceful and equitable resolution of all other unresolved boundaries in the Arctic Ocean. This includes the boundaries involving Russia, which can claim more than 40 per cent of the Arctic shoreline. Given that the United States is not a party to the United Nations Convention on the Law of the Sea, this article focuses on mechanisms available to Canada and the United States under general international law and by applying 'best law' and 'best science'.
\end{abstract}

\section{Keywords}

Arctic Ocean - Beaufort Sea - equidistance - maritime boundaries - United Nations Convention on the Law of the Sea (LOSC) 


\section{Introduction}

Fewer than half of the potential maritime boundary segments in the world have been agreed upon, creating uncertainty not only for the coastal States involved, but also for investors active in the offshore extractive industries and in the fishing industry. The situation is no different in the Arctic Ocean, where a number of boundaries remain to be delimited. Defining with certainty the area of the Arctic seabed and subsoil in which circumpolar countries such as Canada and the United States may exercise their sovereign rights over living marine species and natural resources is critical to their national interests in resource management, energy security and environmental protection.

Coastal States with competing claims to maritime areas routinely offer oil concessions in disputed waters without the investors taking blocks being fully aware of the underlying inter-State dispute and the risks presented by an undelimited boundary, especially one featuring straddling deposits. Underscoring this problem, the US state of Alaska issued a notification of a bid round comprising blocks lying in the area of overlapping claims in the Beaufort Sea that opened on 15 November 2018. ${ }^{1}$

The modern law of the sea, which to a large extent has been codified in the UN Convention on the Law of the Sea (LOSC), ${ }^{2}$ as well as the related concept of maritime boundary delimitation, reflect a mixture of law and science. This calls for a multidisciplinary approach. The interconnection between law (of the sea) and science (of maritime boundary delimitation, or definition, and delineation) is most apparent in Article 76 of the Losc, which concerns the delineation of outer continental shelf limits. That provision incorporates elements in its legal definition that require the input from non-legal boundary specialists, especially geo-scientists. As the International Court of Justice (ICJ) observed in 1982, "the "continental shelf" is an institution of international law which, while it remains linked to a physical fact, is not to be identified with the phenomenon designated by the same term - "continental shelf" in other disciplines. ${ }^{3}$ Yet, as the submissions relating to what is commonly referred to as an 'extended', or 'outer', continental shelf (ECS) filed with the

1 See 'Beaufort Sea Areawide 2018W Competitive Oil and Gas Lease Sale Regional Tract Map' (Division of Oil \& Gas, Alaska Department of Natural Resources) available at http://dog.dnr .alaska.gov/Documents/Leasing/SaleDocuments/BeaufortSea/2018W/Tract_Map_BS2018W .pdf; accessed 14 November 2018; information on Drillinginfo website, available at https:// info.drillinginfo.com/international; accessed 14 November 2018.

2 United Nations Convention on the Law of the Sea (Montego Bay, 10 December 1982, in force 16 November 1994) 1833 UNTS 396.

3 Continental Shelf (Tunisia/Libyan Arab Jamahiriya), Judgment [1982] ICJ Rep 18, at p. 45, para 41. 
Commission on the Limits of the Continental Shelf (CLCS), a body of 21 geoscientists (for the most part) established under the Losc, and the emerging jurisprudence on ECs delimitations highlight, ${ }^{4}$ ultimately, it is science and geography that determine whether a coastal State can lawfully claim sovereign rights over zones of maritime jurisdiction such as the ECS, and to what extent. In addition, the political dimension plays an important role in determining maritime boundaries. Moreover, scientific advancements are driving the development of deep-seabed exploration and exploitation, including in Arctic waters.

Maritime boundary delimitation essentially is a marine application that involves mapping, including of coastlines from which all boundary lines are drawn. As regards the standard for continental shelf delimitation, Article 6 of the 1958 Convention on the Continental Shelf (CCS) lays down the rule that '[i]n the absence of agreement, and unless another boundary line is justified by special circumstances, the [continental shelf] boundary is the median line, every point of which is equidistant from the nearest points of the baselines from which the breadth of the territorial sea of each state is measured'. ${ }^{5}$ This 'equidistance/special circumstances' rule in the CCs, which also is employed for the delimitation of the territorial sea in Article 15 of the Losc, has been assimilated with the rule of general international law requiring an 'equitable result' based upon equitable principles.

Article 6 of the ccs underscores that the identification of baselines on a State's coastline is the starting point for maritime delimitation, at least where equidistance or median lines are used - and equidistance has emerged as the most popular method of maritime delimitation in adjudicated cases. This identification is based on a geo-scientific determination. Without coastlines, one cannot identify baselines - without baselines, it is impossible to define the legal limits of zones of maritime jurisdiction, that is, maritime boundaries. The LOSC recognises two types of baselines, straight (Article 7) and normal (Article 5). In the Beaufort Sea, Canada uses a combination, whereas the United States uses only normal baselines. Straight baselines depict longer, straight-line sections of coastal frontage, closing off erratic or irregular coastal sections. A normal baseline is established by drawing a notional, adjusted coastline that as a general rule tracks the tidal low-water line along the coast based on a complex

4 See, e.g., Dispute concerning the Maritime Boundary between Guyana and Suriname (Guyana v. Suriname), Award, 16 September 2007, Permanent Court of Arbitration (PCA), PCA Case No. 2004-04, available at https://pca-cpa.org; accessed 14 November 2018; Delimitation of the maritime boundary in the Bay of Bengal (Bangladesh/Myanmar), Judgment, ITLOs Reports 2012, p. 4.

5 Convention on the Continental Shelf (Geneva, 29 April 1958, in force 10 June 1964) 499 UNTS 311. 
compilation of proper coastlines and relevant nearshore-foreshore smaller features such as islands, islets, sandbanks, reefs and rocks. In order to identify a normal baseline one needs to specify a certain geodetic datum in order to take into account the curvature of the Earth. A datum is often lacking in the older nautical charts that reflect a 'pencil-and-ruler' approach. The level of sophistication of mapping technology determines the accuracy of the basepoints on baselines.

For purposes of maritime boundary delimitation based on nautical charts, the United Nations recommends that 'in general the scale should be within the range 1:50,000 to 1:200,000.6 Modern topographical techniques such as LiDAR, a surveying method that measures distance to a target by illuminating the target with pulsed laser light and by measuring the reflected pulses with a sensor, can produce far more accurate maps reflecting sub-metre deviations. Nowadays, sophisticated boundary desktop mapping software such as CARIS-LOTS ${ }^{7}$ and satellite imagery can assist in the task of determining baselines with pinpoint accuracy, thereby contributing to the certainty and stability of maritime boundaries. This article applies the latest imaging techniques in combination with CARIS-LOTS in plotting the Canada-United States boundary in the Beaufort Sea.

A body of maritime delimitation case law has developed through some 25 decisions rendered by international courts and tribunals since 1969. ${ }^{8}$ These decisions allow for a 'reverse-engineering' of adjudicated boundaries and the lessons from the case law can be applied to a given undelimited boundary. In this article, we apply this technique and jurisprudential framework in analysing the situation regarding the Canada-United States boundary in the Beaufort Sea and in predicting a boundary that reflects 'best law' and 'best science'.

The section that follows first sets out the digital datasets that we have employed for this article. This will be followed by a description of the geographical and historical background relating to the unresolved boundary in the Beaufort Sea. This is followed by a summary, split into two sections, of the respective positions of Canada and the United States with regard to the Beaufort Sea

6 See The Law of the Sea-Baselines: An Examination of the Relevant Provisions of the United Nations Convention on the Law of the Sea (United Nations Office for Oceans Affairs and the Law of the Sea, UN Sales No. E.88.V.5, 1989) at p. 2, n 8 to Article 5 ('officially recognized charts').

7 See the Teledyne CARIS website, available at https://teledynecaris.com; accessed 14 November 2018.

8 For an overview, and the full text, of these decisions, see the Dundee Ocean and Lake Frontiers Institute and Neutrals (DOLFIN) website, available at https://sites.dundee.ac.uk/ dolfin/; accessed 14 November 2018. 
boundary based on publicly available documents and information. Following this summary, the next section identifies the oil and gas blocks that have been issued by the two countries in the area where they are claiming that the boundary in the Beaufort Sea is located. This is followed by a description of the applicable legal framework and methodology underlying a jurisprudence-based resolution of the Canada-United States boundary in the Beaufort Sea. For this purpose, we will apply the 'three-step' methodology that has been developed in the maritime delimitation jurisprudence. The final section of this article presents our conclusions.

\section{Assembling the Desktop Study}

For all law of the sea (LOS) projects pertaining to any of the world's coastal States, best practice dictates the assembly of a complete 'LOs Desktop Study' (LOS-DTS). The maritime boundary being analysed in detail will require a broader regional study of the area of interest (AOI) for the LOS-DTS datasets in order to allow for a larger area to be properly analysed. For the LOS-DTS study developed for this article, a digital map, at scale 1: 7,500,000, was selected, in a UTM projection, Zone 7, with WGS84 Datum and 0.25 metres ground resolution. Table 1 below sets out the digital datasets used in assembling the Beaufort Sea Los-DTS. ${ }^{9}$

\section{Geographical and Historical Background}

\section{Geography and Topography}

The Beaufort Sea is an area of the Arctic Ocean situated along the northern coast of the US state of Alaska and the Yukon and the Northwest Territories in Canada. This relatively shallow expanse of sea covers approximately 184,000 square miles, ${ }^{10}$ stretching from Point Barrow, Alaska, in the west, to Lands

$9 \quad$ Proprietary Fugro Global Law of the Sea Database, containing law of the sea (LOS) relevant digital datasets, with global coverage (containing in excess of 85 terabytes of digital data) and more than 10,0oo legal Los documents (most of which are not in public circulation) that were acquired by working on more than 1,500 Los studies in 142 of the 162 countries eligible for Los applications. All the figures in this article make use of that information.

10 'Beaufort Sea' in Encyclopaedia Britannica (Encyclopaedia Britannica Inc.), available at https://britannica.com/place/Beaufort-Sea; accessed 9 August 2018 (hereinafter Encyclopaedia Britannica). 
TABLE 1 Datasets underlying the Beaufort Sea Desktop Study

A. Coastlines

World Vector Shorelines (wVs) (1994) ${ }^{\mathrm{a}}$ (positionally accurate $+/-1$,ooo metres and worse in the Arctic) WVS II $(2004)^{b}$ (positionally accurate $+/$ - 100 metres and worse in the Arctic)

B. Territorial Sea Baseline Model (TSBM) for Coastal States

United States TSBM not published (gazetted)

The United States only uses 'normal baselines' for all Los mathematical measurements (only 'source' possible is from the National Oceanic and Atmospheric Administration (NOAA) large-scale nautical charts by digitizing coastlines)

Canada TSBM (published (gazetted))

Canada uses combinations of 'straight baselines' and 'normal baselines'

\section{Los 'Legal Limits'}

United States

o-3 nautical miles $(\mathrm{M})$ (state limit)

3-12 M (federal territorial sea)

12-24 M (federal contiguous zone)

24-200 M (federal EEz)

Canada

o-12 M (territorial sea)

12-24 M (contiguous zone)

24-200 M (EEZ)

\section{Maritime Boundaries}

United States and Russia (west of LOS-DTS AOI), Treaty of 1 June 1990

Following the maritime boundary line principle of a 'meridian line'

Canada and Denmark (Greenland)c (east of LOS-DTs AOI), Treaty of 17 December 1973

Following the maritime boundary line principle of a 'strict equidistance line'

United States and Canada (analysis for this LOS-DTS), unresolved (US unilateral line)

Following the maritime boundary line principle of a 'strict equidistance line' 
TABLE 1 Datasets underlying the Beaufort Sea Desk top study (cont.)

Canada and United States (analysis for this Los-DTs), unresolved (Canadian unilateral line)

Following the maritime boundary line principle of a

'meridian line'

\section{E. Land Terminus Point (LTP)}

(a)

(b)

(c)

\section{F. Use of US NOAA Nautical Charts ${ }^{g}$ \\ G. Use of Modern-day Landsat TM8 ${ }^{\text {h }}$ (recent) Imagery to (i) Perform Quality}

Control Checks, and (ii) Interpret and Update the тsв and Canada ${ }^{\mathrm{i}}$

\section{H. Regional Oil \& Gas Blocks}

a See 'World Vector Shorelines' (NOAA), available at https://shoreline.noaa.gov/data/ datasheets/wvs.html; accessed 4 August 2018.

b See 'Shoreline/Coastline Resources' (NOAA), available at https://www.ngdc.noaa.gov/mgg/ shorelines/; accessed 14 August 2018,

c See 'Agreement between the Government of the Kingdom of Denmark and the Government of Canada relating to the Delimitation of the Continental Shelf between Greenland and Canada (17 December 1975), available at http://www.un.org/Depts/los/LEGISLATIONANDTREATIES/ PDFFILES/TREATIES/DNK-CAN1973CS.PDF; accessed 14 August 2018.

d See (1995) 6o(163) US Federal Register (23 August 1995) ('Notices / USA EEZ Public Notice PDF' (see Alaska)).

e See Territorial Sea Geographical Coordinates (Area 7) Order, SOR/85-872 (Canada), available at http://laws-lois.justice.gc.ca/eng/regulations/SOR-85-872/page-1.html; accessed on 14 August 2018.

f For this LOS-DTS to be as accurate as possible, the above LTP was used for all calculations. As the Gazetted US LTP (a) and the Canadian Gazetted LTP (b) do not match, we will use (c). In the LOS-GIS, the US LTP is 65.3 metres northwest (in the water), and the Canadian LTP is 138.1 metres southwest (well inland). For Los purposes, the LTP by definition is the exact land versus sea transition point. As neither the US LTP nor the Canadian LTP meets this criterion, a new one was chosen by us in order to improve the overall accuracy of the LOS-DTS. 
g See 'Electronic Charts (ENC)' (NOAA), available at http://www.charts.noaa.gov/ InteractiveCatalog/nrnc.shtml; accessed on 14 August 2018. In all, 29 individual large-scale (1: 50,000) published NOAA ENC Digital (GIS-ready) nautical charts are available. These are recently published (all are dated 1 January 2015). However, the surveying used to make the charts, coastlines and nearshore shallow waters occurred during the period 1940-1969, so that all positional accuracies are questionable. For our LOS-DTS, 14 individual NOAA nautical charts were used to review and analyse the entire US coastal waters. It is only this source that will offer exactly what the US Government uses for its non-gazetted normal baselines.

h See https://lta.cr.usgs.gov/L8; accessed on 14 August 2018.

i In all, seven individual Landsat TM 2017 and 2018 satellite images were used in order to quality control (QC) and/or update the missing normal baselines for both the United States and Canada. The QC of the Canadian straight baselines showed that several locations were off (all less than 1,00o metres), which should be properly updated as they are based on old (1985) mapping standards. With advancement in technology, dramatic improvements can and likely would be achieved. However, for this LOS-DTs, as those were actual 'gazetted geographic coordinates', they were simply used as-is. When and if a more detailed Los-DTs is required, as this will take a greater amount of time to complete, it is advisable to get the updating done in order to increase the level of accuracy of the Los-DTs' final results. The new 4DSSM (satellite seafloor morphology) image analysis technique was employed for some of the more critical offshore fringing islands along the US maritime frontier waters. See $\mathrm{R}$ van de Poll, Paper and PowerPoint Presentation OTC-29178-MS, АтC-отC, 5 November 2018, available at http://otcnet.org/arctic; accessed 14 November 2018. For present-day, present-use US normal baselines (based on NOAA 2015 large-scale nautical charts), that paper offers detailed analysis and findings for the US normal baselines, which can easily be off by as much as 2,500 metres on the ground.

End, Prince Patrick Island, Northwest Territories, in the east. ${ }^{11}$ The unresolved Beaufort Sea boundary concerns a wedge-shaped section of that sea that sits north of the land border between Canada and the United States. The disputed area, which measures around 6,250 square nautical miles (M), is the segment lying within the 200-M limit from the coast between (i) the 141st degree meridian line; and (ii) the 'strict' equidistance line between the Canadian and US coasts. That equidistance line extends from the edge of the land border at a perpendicular angle to the coastline and falls east of the 141st degree meridian. ${ }^{12}$

The surface of the Beaufort Sea presently remains entirely frozen for a considerable portion of the year. ${ }^{13}$ Some thawing occurs in the months of August and September, but only in those sections of the sea that are proximate to the

\footnotetext{
11 International Hydrographic Organization, Limits of Oceans and Seas (3rd ed., Imp. Monégasque, Monte Carlo, 1953).

12 M Byers and A Østhagen, 'Why Does Canada Have So Many Unresolved Maritime Boundary Disputes?' (2017) 54 Canadian Yearbook of International Law 1-62, at p. 12.

13 See E Bush and DS Lemmen (eds), Canada's Changing Climate Report (Government of Canada, Ottawa, April 2019), available at https://changingclimate.ca; accessed 10 April 2019 .
} 
coast. ${ }^{14}$ The sea sits atop a relatively narrow continental shelf, which extends no more than go kilometres from the mainland coast at any point. It is fed by dozens of rivers, including the Mackenzie, which deposits around 15 million tons of sediment every year. ${ }^{15}$

Despite its harsh icy climate, the Beaufort Sea is home to a rich ecosystem of wildlife. Beluga and bowhead whales, polar bears, seabirds and an abundance of other migratory species can be found both above and below the sea ice. ${ }^{16}$ Human activity at present, by contrast, is relatively limited in the area. While melting sea ice has made this region of the Arctic Ocean increasingly accessible to fishing vessels, both Canada and the United States have taken measures to curtail commercial fishing off their northern coasts, and currently only subsistence fishing and hunting for the supply of the local population takes place. ${ }^{17}$ In 1984, Canada entered into the Inuvialuit Final Agreement, in which the Canadian government recognised, and undertook to protect, the fishing rights of the native Inuvialuit people living in the area. ${ }^{18}$

The most significant settlement along the coast, Prudhoe Bay in Alaska, serves as a hub for petroleum production workers, and it features the TransAlaska Pipeline connecting Prudhoe Bay's oil fields with the southern Alaskan port of Valdez. ${ }^{19}$ As detailed below, extensive hydrocarbon reserves have been discovered in the Beaufort Sea since the 197os. ${ }^{20}$

\section{Historical Background}

While the substance of the boundary disagreement between Canada and the United States is derived from treaties concluded in the nineteenth century, the controversy itself did not materialise until the mid-1970s. It sprang from

\footnotetext{
14 Ibid.

15 Encyclopaedia Britannica (n 10).

16 'Beaufort Sea: Connected, Protected, Respected: Conserving the Beaufort Sea Ecosystem' (World Wildlife Fund Canada), available at http://www.wwf.ca/conservation/arctic/ beaufort_sea/; accessed 13 August 2018.

17 'Beaufort Sea commercial fishing banned' (Свс News) 15 April 2011, available at https:// www.cbc.ca/news/canada/north/beaufort-sea-commercial-fishing-banned-1.1028286; accessed 13 August 2018. See also N Harley, 'Russia and US join global pact to restrict fishing in thawing Arctic in deal to protect marine life' The Telegraph, 3 December 2017, available at https://www.telegraph.co.uk/news/2017/12/o2/arctic-fishing-banned-global-dealprotect-marine-life/; accessed 13 August 2018.

18 'Inuvialuit Final Agreement as Amended' Inuvialuit Regional Corporation, 1984, available at https://www.irc.inuvialuit.com/sites/default/files/Inuvialuit\%2oFinal\%2O Agreement\%202005.pdf; accessed 13 August 2018.

19 Encyclopaedia Britannica (n 10).

20 Byers and Østhagen (n 12), at p. 15.
} 
the delineation by each country of the territory it deemed to be within its 20o-M zone. In 1976 and 1977, Canada and the United States each contested the lines the other had used in drawing up its fisheries zones and granting oil and gas concessions in the Beaufort Sea. ${ }^{21}$ Prior to this point, and the introduction of the practice of claiming exploitation rights in a 200-M exclusive economic zone (EEZ), coastal States had paid little attention to boundaries delimiting such a zone. ${ }^{22}$

The roots of the disagreement can be traced back to the conclusion by Russia and Great Britain of the 1825 Treaty of St. Petersburg, which concerned the regions that now form Alaska and Canada. ${ }^{23}$ The Treaty, originally written in French, dictated that the demarcation between the territories of Russia and Great Britain in the northwest of America be drawn along the 141st meridian and that this border was to extend 'jusqu'à la Mer Glaciale' (in English, 'as far as the Frozen Ocean'). ${ }^{24}$ The United States acquired Russia's rights under this treaty on 30 March 1867 , when it purchased Alaska, ${ }^{25}$ while Canada inherited Great Britain's treaty rights on 1 July 1867 , when it gained independence as a sovereign State. ${ }^{26}$

While the controversy over the Beaufort Sea boundary persists, one might better describe it as a 'managed disagreement', which has seen several attempts at reconciliation since it arose. Negotiations took place in 1977 and 1978 between Canada and the United States with respect to four maritime boundaries, including the Beaufort Sea boundary. ${ }^{27}$ It has been reported that Canada entered these talks prepared to make concessions in respect of the Beaufort Sea boundary, in return for gains from the United States in respect of other maritime boundaries, such as those in the Gulf of Maine. ${ }^{28}$ Ultimately,

21 Ibid., at p. 11; see, generally, M Byers, International Law and the Arctic (1st paperback ed., Cambridge University Press, Cambridge, 2013), at pp. 56-91.

22 D McRae, quoted in S Griffiths, 'US-Canada Arctic border dispute key to maritime riches' (ввс News) 10 August 2010, available at https://www.bbc.co.uk/news/world-uscanada-10834006; accessed 9 August 2018.

23 Great Britain/Russia: Limits of their Respective Possessions on the North-West Coast of America and the Navigation of the Pacific Ocean, 16 February 1825, 75 Consolidated Treaty Series 95 .

24 Ibid.

25 Treaty concerning the Cession of the Russian Possessions in North America to the United States of America, signed on 30 March 1867, available at http://avalon.law.yale.edu/19th century/treatywi.asp; accessed 14 November 2018.

26 Canada, Senate Standing Committee on National Security and Defence, Sovereignty \& Security in Canada's Arctic: Interim Report (Senate, Ottawa, March 2011), at p. 33 (hereinafter Interim Report).

27 Byers and Østhagen (n 12), at p. 5; Byers (n 21), at p. 62.

28 Byers and Østhagen, ibid. 
no such progress was made. With the United States insisting on negotiating each boundary on an individual basis, and Canada apparently being fearful of setting legal precedents that could harm its position in other disputed areas, the two countries focused their attention on settling the most pressing of their boundary disagreements, namely, the Gulf of Maine boundary. ${ }^{29}$ Each boundary delimitation situation is unique and States are known to be concerned about what might be termed the optics or knock-on effects of taking a position in one dispute that is contradictory with that in another boundary situation.

Further talks occurred in 2010 and 2011 during Lawrence Cannon's tenure as Canada's Minister of Foreign Affairs. However, these talks were halted, partly on the basis that both countries wished to gather more data on the extent of the existence of oil and gas deposits in the disputed area before cementing their negotiating positions. ${ }^{30}$ These talks took place against a backdrop of years of joint mapping exercises, in which Canadian and US scientists and coast guard officials worked together on expeditions aimed at gathering data for their respective ECS claims. ${ }^{31}$ In doing so, each country sought to collect proof demonstrating that the continental shelf stretches further into the Beaufort Sea than originally thought, and thereby increase the scope of their claims of sovereign rights over submerged territory under the technical provisions for making such a determination under the LOSC. ${ }^{32}$

29 Ibid., at pp. $5^{-6}$. We note that there is no evidence suggesting that the purpose of the bilateral negotiations was simply to formalise a maritime boundary tacitly agreed upon between Canada and the United States. Thus, an international tribunal unlikely would be tasked with determining whether a tacit maritime boundary exists between Canada and the United States. The only case in which the existence of a tacit agreement was recognised was the case between Peru and Chile before the ICJ. See Maritime Dispute (Peru v. Chile), Judgment, [2014] ICJ Rep 3.

30 See Dispute concerning delimitation of the maritime boundary between Ghana and Côte d'Ivoire in the Atlantic Ocean (Ghana/Côte d'voire), Judgment, ITlos Special Chamber, Case No. 23, 23 September 2017, pp. 14-15, available at https://www.itlos.org/fileadmin/ itlos/documents/cases/case_no.23_merits/C23_Judgment_23.09.2017_corr.pdf; accessed 28 August 2018 (hereinafter Atlantic Judgment). For a review of that ruling by the present authors, see P Bekker and $\mathrm{R}$ van de Poll, 'Ghana and Côte d'Ivoire Receive a StrictEquidistance Boundary' (2017) 21(11) ASIL Insights, 13 October 2017, available at https:// www.asil.org/insights/volume/21/issue/11/ghana-and-cote-divoire-receive-strictequidistance-boundary; accessed 28 August 2018.

31 B Baker, 'Filling an Arctic Gap: Legal and Regulatory Possibilities for Canadian-U.S. Cooperation in the Beaufort Sea' (2009) 34 Vermont Law Review 34-57, at p. 57.

32 Griffiths (n 22). 


\section{Summary of Canada's Position}

Canada's position, at least as concerns the maritime area extending to $200 \mathrm{M}$, is that the Beaufort Sea boundary should be delineated pursuant to the wording found in the 1825 Treaty of St. Petersburg. In Canada's view, that wording should be interpreted as confirming that the land border separating Alaska in the United States with the Yukon in Canada continues out into the Arctic Ocean along the 141st meridian line. ${ }^{33}$

While Canada has shown some willingness to trade concessions with regard to the Beaufort Sea boundary during previous negotiations with the United States, its position in respect of the correct placement of the boundary is cemented by a number of factors. One such factor, as referenced above, is that the Beaufort Sea is just one of several maritime boundary disagreements that Canada contends with, and in ceding ground in the one dispute it risks prejudicing itself in others. Another factor is the agreement reached by the Canadian government with the Inuvialuit to protect their rights in the region. ${ }^{34}$ This agreement uses the 141st meridian line to delineate the extent of the Inuvialuit Settlement Region and making boundary concessions to the United States could consequently represent an infringement of Inuvialuit rights that are protected under Canadian law. ${ }^{35}$ Canada has been swift to condemn any perceived infringement of its sovereignty or sovereign rights in the area, as witnessed in 2016 when a proposal by the US Bureau of Ocean Energy Management (воЕм) for new exploration leases in the disputed area was met by protest from Yukon's authorities. ${ }^{36}$

There is some support in State practice and international jurisprudence for Canada's position that the boundary in the Beaufort Sea should be delimited by reference to the 141st meridian line, that is, based on the parallel-of-latitude method. Thus, the Arctic boundary between the United States and Russia, lying to the west of the Beaufort Sea, extends north along the $168^{\circ} 5^{\prime} 37^{\prime \prime}$ meridian

33 Interim Report (n 26), at p. 33 .

34 Inuvialuit Final Agreement (n 18).

35 Byers and Østhagen (n 12), at p. 18; Byers (n 21), at pp. 8o-82.

36 G Sharp, 'An old problem, a new opportunity: A case for solving the Beaufort Sea boundary dispute' (The Arctic Institute) 17 June 2016, available at https://www.thearcticinstitute .org/an-old-problem-a-new-opportunity-a-case-for-solving-the-beaufort-sea-boundarydispute/; accessed 9 August 2018. It is beyond the scope of this article to assess whether, by its acts, Canada or the United States is estopped from objecting to a boundary based on equidistance or a parallel-of-latitude method, respectively, or whether there is acquiescence of any sort. 
through the Bering Strait and Chukchi Sea into the Arctic Ocean. ${ }^{37}$ In other words, the United States appears to have applied the parallel-of-latitude method in delimiting its maritime boundaries with third States in the region. In 2014, the ICJ held that there was an agreed maritime boundary between Peru and Chile extending to a distance of $80 \mathrm{M}$ along the parallel of latitude passing through the starting point of the Peru-Chile land border, while imposing a boundary line reflecting 'strict' (i.e., unmodified) equidistance beyond $80 \mathrm{M}^{38}$ At the same time, Canada appears to be advocating a strict equidistance line for its Arctic boundary with Greenland/Denmark, which lies to the east of the Beaufort Sea.

In Fig. 1 below, Canada's position regarding the boundary with the United States in the Beaufort Sea is represented by a straight dashed line. The line starts from the LTP, represented by a white star on the coastline. This unilateral line reflects one country's position and follows the land border between Canada and the United States along the 141st degree 'line of longitude'. Canada simply projects the line seaward until it intersects the regional 200-M (EEZ) legal limit. This type of computed maritime boundary line is based on the 'sector line principle'.

\section{Summary of the United States' Position}

The US policy in respect of the Beaufort Sea is to recognise a boundary between itself and Canada in the Beaufort Sea based on equidistance, at least as concerns the maritime area extending to $200 \mathrm{M} .{ }^{39}$ That is to say, its delineation would put the maritime boundary at a median line that extends from the terminus of the land border on the coast at a perpendicular angle and at each point represents the middle point between the coasts of Canada and the United States. In taking this position, the United States rejects the interpretation of the wording of the 1825 Treaty of St. Petersburg advocated by Canada. The United States instead takes the view that the wording of the Treaty intended the border to follow the 141st meridian up until the shoreline only, and that

37 The United States and the UssR, the predecessor of the Russian Federation, concluded a maritime boundary treaty on 1 June 199o, but it is unclear whether that treaty has entered into force for the United States and Russia. A legal analysis of the United States-Russia boundary in the Arctic is beyond the scope of the present article.

38 See Maritime Dispute (Peru v. Chile), Judgment, [2014] ICJ Rep 3.

39 'National Security Presidential Directive / NSPD - 66: Arctic Region Policy' (The White House: Office of the Press Secretary, 9 January 20o9) at p. 6, available at https://fas.org/ irp/offdocs/nspd/nspd-66.pdf; accessed 14 August 2018. 


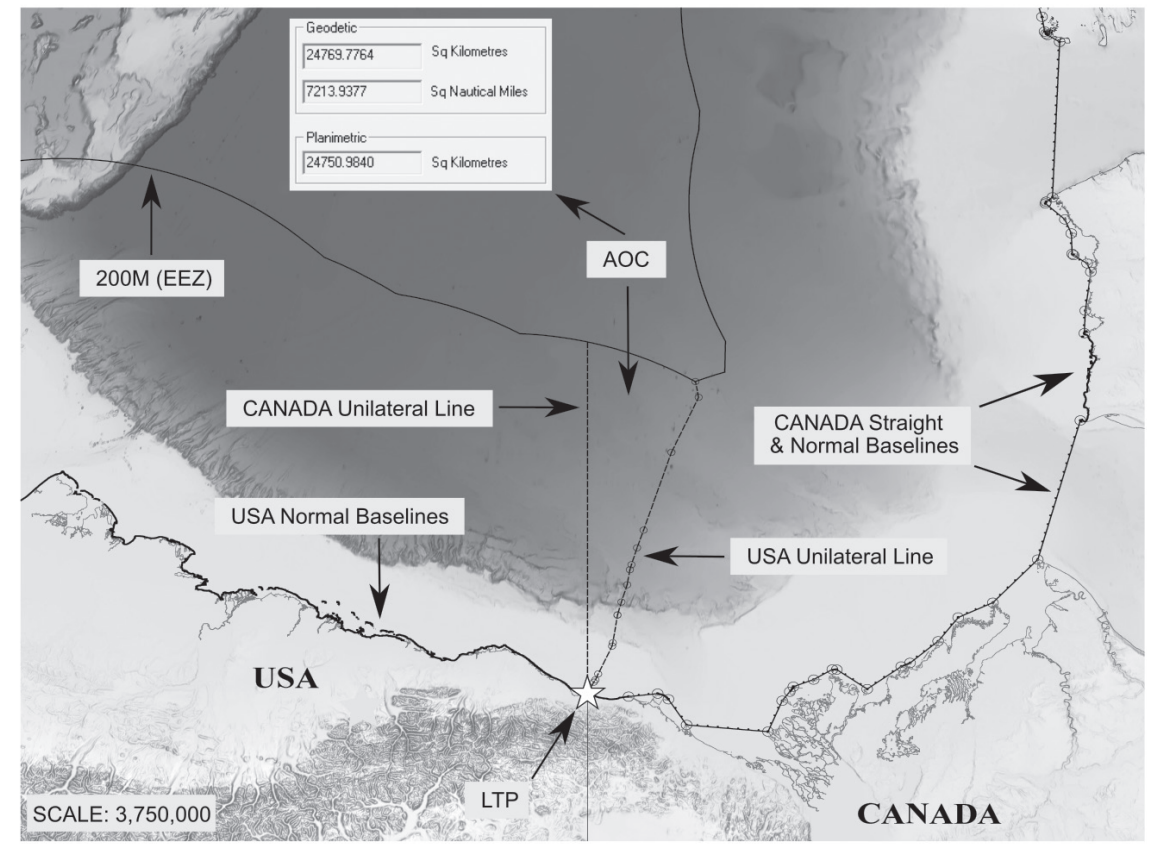

FIGURE 1 Boundary lines and baselines claimed by Canada and the United States

the equidistance method should be applied when extending the border out to sea. ${ }^{40}$ Like Canada, it appears that the United States' ability to negotiate its position on the Beaufort Sea boundary has been tempered by a fear of creating precedents that may harm its position in other prevailing and future disputes, both with Canada and with other States. ${ }^{41}$

As mentioned above, the principle of equidistance is confirmed in the LOSC and in international jurisprudence with respect to the territorial sea. However, in contrast to Canada and all other Arctic circumpolar countries, the United States has yet to ratify the LOSC. ${ }^{42}$ This means that the provisions of the LOSC, including those on the ECS, are not opposable to the United States as treaty (conventional) law. The US government's official policy regarding the LOSC is that the US Senate should 'act favorably' on prompt accession in order to protect and advance the United States' interests in the Arctic. ${ }^{43}$ As such, while

$40 \quad$ Interim Report (n 26), at p. 33 .

41 Byers and Østhagen (n 12), at p. 5 .

42 National Security Presidential Directive (n 39).

43 Ibid., at p. 5. See also Byers (n 21), at pp. 5-6. 
not yet a party to the LOSC, the United States has committed to 'continue to support and observe principles of established customary international law reflected in the Convention.44

Fig. 1 also shows the boundary line up to $200 \mathrm{M}$ that we believe reflects the United States' position regarding the boundary with Canada in the Beaufort Sea. The boundary as gazetted is represented by a dashed line with round symbols..$^{45}$ The line starts from near the LTP identified by us elsewhere in this article. This unilateral line reflects one country's position and was computed using both the US тSвм (i.e., normal baselines, represented by lines along US coastlines and coastal frontages west of the white star shown in Fig. 1) as well as Canada's тSвм (i.e., a combination of both normal baselines and straight baselines, represented by lines along Canadian coastlines and coastal frontages east of the white star shown in Fig. 1).

As this line was described in an official gazette, ${ }^{46}$ it is simply assumed that the United States used all relevant regional baselines, similar to those as shown by us. For this Los-DTs, and this specific unilateral line, the gazetted coordinates were imported in the LOS-DTS and connected to produce the line as shown in Fig. 1. This type of computed maritime boundary line is based on the strict (theoretical) equidistance line method. We note that, based on our detailed review of the LTP, the US gazetted line does not start exactly on the LTP that was identified by us in the LOS-DTS, but appears to start offshore (in the water) at a distance of 65.3 metres northwest from this LOS-DTS suggested interpreted position, relying on 2018 data sources.

Fig. 1 details the results for both the United States and Canada based on their claimed maritime boundary lines, as they intersect the 200-M EEz limit. The close-shaped polygon area, commonly referred to as the 'area of overlapping claims' (AOC), is shown as $24,769.77$ square kilometres (geodetic) or 7,213.93

\footnotetext{
44 'National Strategy for the Arctic' (The White House, 10 May 2013), available at https:// obamawhitehouse.archives.gov/sites/default/files/docs/nat_arctic_strategy.pdf; accessed 14 August 2018. The United States has not specified which parts of the LOSC it sees as being, or not being, reflective of customary international law. The published geographic coordinates of the turning points (in NA27 Datum) are available at https://www.un.org/Depts/los/LEGISLATIONANDTREATIES/PDFFILES/ USA_1995_eez_public_notice.pdf on page 43827; accessed 1 June 2019.

46 (1995) 6o(163) US Federal Register (23 August 1995) ('Notices / USA EEZ Public Notice PDF' (see Alaska)).
} 
square $\mathrm{M}$ (geodetic). ${ }^{47}$ Offshore activities that take place inside these AOC waters run the risk or uncertainty of ownership of the seabed and related seabed resources associated with the disputed waters.

\section{Oil and Gas Blocks in the Area of Overlapping Claims}

Based entirely on third-party datasets available from Drillinginfo, ${ }^{48}$ the following information regarding oil and gas blocks issued by Canada and the United States was identified in the AOC at the time of writing. Fig. 2 below details the offshore concession blocks defined or opened for bid round by the вовм at the time of writing. The image shows that the entire US claimed offshore maritime frontier is covered by open blocks. Some 15,469 individual offshore blocks are shown as small boxes. The actual present-day issued blocks, representing production sharing contracts (PSCs), total $5^{26}$ blocks.

While difficult to see in the small-scale image in Fig. 2, among the US open blocks lying in proximity to the computed hypothetical strict equidistance line, multiple blocks lie east of this produced line, that is, they could be considered as 'encroaching' into Canadian would-be waters if this line was adopted. Interestingly, the вовм has laid out open blocks well beyond the United States' EEZ limit. Eventually, some or all of this could become US seabed under their ECS claim, if successful. All present-day issued PSC blocks shown are nowhere near the yet-to-be-resolved Canada-United States boundary. Therefore, for US offshore acreage held by international oil companies, this does not appear to be an issue from a maritime boundary point of view. ${ }^{49}$

47 As they concern offshore areas, global Los applications require the accuracy associated with geodetic calculations. Such calculations use a latitude and longitude coordinate system on an ellipsoidal Earth model, thereby properly treating the Earth as a globe. Sometimes planametric calculations are used, which essentially approximate the round surface of the Earth by projecting it onto a flat plane, thereby causing distortions at the edges and producing less accurate results and calculations for offshore Los applications.

48 Fugro has an annual subscription to Drillinginfo, a global database showing oil and gas concession blocks worldwide, as part of its Global Law of the Sea analysis services. The information used in this article is based on the August 2018 edition of Drillinginfo, available at https://info.drillinginfo.com/industry/international.

49 However, there is one possible issue, internal to the United States, where state (o-3 M waters) versus federal (3-12 $\mathrm{M}$ waters) could see positional mapping discrepancies, as present-day PSC blocks issued to IOCs likely do not lie in the waters (state versus federal) based on older 1940-196os mapping. A more detailed analysis goes beyond the scope of this article. 


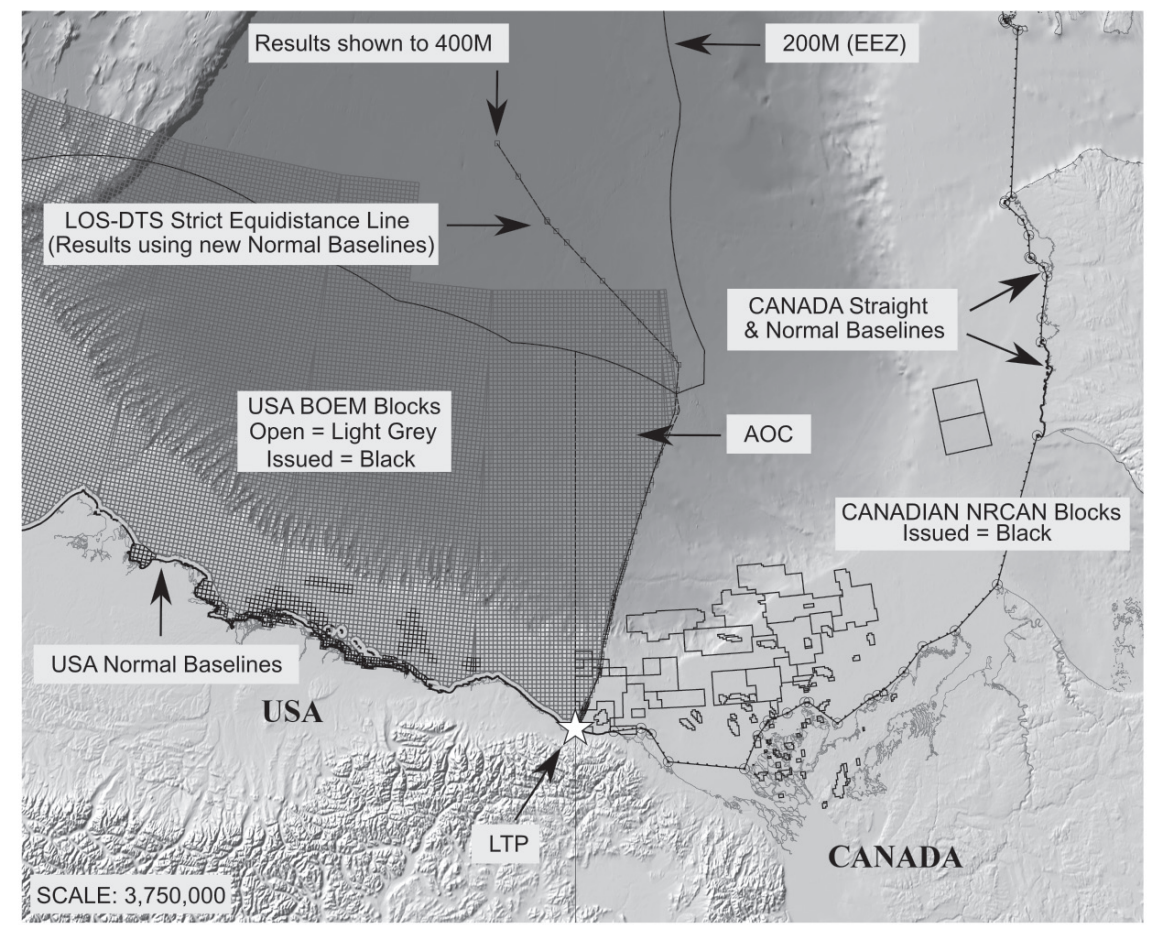

FIGURE 2 Open and issued offshore concession blocks in the Beaufort Sea (SOURCE: DRILLINGINFO)

Fig. 2 also details the offshore oil and gas concession blocks defined by the Canadian government at the time of writing. The image shows only presentday issued PSC blocks. The 109 individual offshore blocks are shown as small boxes. While difficult to see in the small-scale image in Fig. 2, the Canadian issued blocks lie in close proximity to the Canadian unilaterally claimed maritime boundary (sector) line, represented by the straight dashed line from this LOS-DTS. The actual PSC blocks do show some minor mismatches west of the computed line, that is, they could be considered to be encroaching into US would-be waters if this line was adopted.

Fig. 3 shows the Canadian issued offshore oil and gas blocks, defined as falling inside the AOC at the time of writing. Of the 109 issued PSC blocks (shown in Fig. 2), five fall inside the AOC in whole or in part (closest to the meridian line) and present possible issues. Fig. 3 also shows the 1,134 US open offshore blocks, defined by the вовм, that fall inside the Aос. Although these US blocks are open, they do not present an immediate problem, at least not until such time that the United States decides to issue these blocks. 


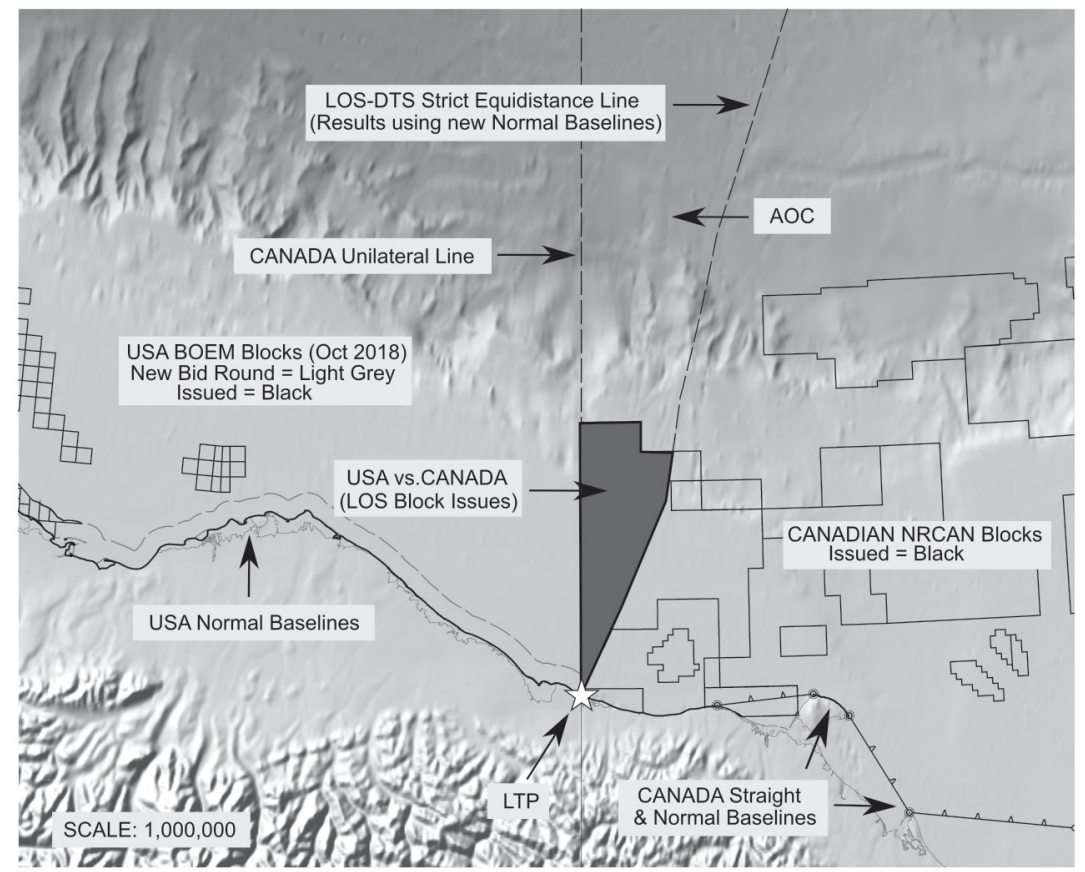

FIGURE 3 Offshore concession blocks in the area of overlapping claims

\section{Jurisprudence-based Boundary Delimitation}

Article 33 of the UN Charter sets out the principal means for the UN member States, including Canada and the United States, to settle their disputes peacefully based on the principle that all States enjoy sovereign equality. ${ }^{50}$ These means range from negotiation to adjudication by an international court or tribunal. In terms of policy options, coastal States with overlapping claims to maritime areas have a basic choice between finding a bilateral solution and seeking third-party assistance. The two disputing States can seek to delimit their maritime boundary, which is the most preferable solution, through bilateral negotiations or through non-binding conciliation or mediation by a third party. Alternatively, the boundary dispute can be submitted to a third-party adjudicated solution, either through ad hoc arbitration or through adjudication by a standing tribunal, with the resulting decision being binding on both parties (but not on third States). ${ }^{51}$

50 Charter of the United Nations (24 October 1945), 1 UNTS XVI, Article 2(1).

51 Ibid., Article 33. Also, as a rule, a delimited boundary between one of the parties and a third State cannot be considered relevant for the delimitation of a boundary between the 
The preferable method for delimiting the Canada-United States boundary in the Beaufort Sea would be through the conclusion by the two States of a bilateral treaty specifying the coordinates of the maritime boundary separating their respective areas of sovereignty and sovereign jurisdiction. A bilateral treaty is dependent upon the mutual consent of the sovereign parties and no sovereign State can be forced to conclude a treaty with another sovereign State. However, States, especially neighbouring States, are under an international law obligation to act and negotiate in good faith. ${ }^{52}$

Under the law of the sea, different rules apply to the delimitation of territorial seas and the delimitation of an EEZ and the continental shelf. As regards the delimitation of the territorial sea between States with adjacent or opposite coasts, Article 15 of the LOSC provides that

neither of the two States is entitled, failing agreement between them to the contrary, to extend its territorial sea beyond the median line every point of which is equidistant from the nearest points on the baselines from which the breadth of the territorial seas of each of the two States is measured.

Article 15 underscores that neighbouring coastal States as a rule are to agree between themselves the limits of the territorial sea, a maritime area within which the coastal State exercises full sovereignty. In the event that they are unable to reach agreement, Article 15 dictates that the boundary in the territorial sea shall be the median line. However, this fall-back rule applies only in a situation where both States have ratified the LOsC. Not having ratified the LOSC, Article 15 is not opposable to the United States. Still, Article 15 probably reflects contemporary customary international law and is binding on the United States as such, unless the United States were on record for consistently opposing the customary status of the rules embodied in Article 15, the wording of which is almost identical to that of Article 12 of the 1958 Convention on the Territorial Sea to which the United States is a party. We are not aware of such opposition. As a matter of fact, it has been the constant policy of the United States to apply the provisions of the LOSC de facto as a matter of policy. The final sentence of Article 15 provides for an exception to the equidistance rule in the event of the

parties. See Maritime Delimitation in the Caribbean Sea and the Pacific Ocean (Costa Rica v. Nicaragua), Judgment, ICJ, 2 February 2018, para 134, available at https://www.icj-cij.org/ en/case/157/judgments; accessed 14 November 2018. 
existence of a historic title or other special circumstances dictating that equidistance not be applied to a territorial sea delimitation.

The 1958 Geneva Conventions do not address the EEZ, a relatively modern concept. Within the EEZ, which must be declared by a coastal State and cannot exceed $200 \mathrm{M}$ from the baselines of the coastal State, a coastal State may exercise exclusive sovereign rights over the natural resources of the water column. Under the LOsC, Canada, a party, has declared a 200-M EEz, and so has the United States.

As regards the continental shelf, the only legal instrument binding on both Canada and the United States is the ccs. According to Article 6 of the ccs, '[i]n the absence of agreement, and unless another boundary line is justified by special circumstances, the boundary is the median line.... Therefore, the continental shelf in the Beaufort Sea would be determined by an international court or tribunal according to a theoretical median (equidistance) line, unless there are 'special circumstances' such as offshore islands or other maritime features.

The LOSC provides substantially identical rules with regard to the delimitation of the EEz and the continental shelf. According to Article 74(1) of the LOSC, "[t] he delimitation of the exclusive economic zone between States with opposite or adjacent coasts shall be affected by agreement on the basis of international law, as referred to in Article 38 of the ICJ Statute, in order to achieve an equitable solution'. In other words, States parties to the LOSC with overlapping EEZ claims are obligated to affect an EEz delimitation through agreement, typically a treaty, and international law shall govern this process. The ICJ has held that Article 74, as well as Article 83 governing the continental shelf, reflect contemporary customary international law. These provisions can be said to be binding on Canada as conventional law and on the United States as customary law. ${ }^{53}$

According to Articles 74(2) and 83(2) of the Losc, '[i]f no agreement can be reached within a reasonable period of time, the States concerned shall resort to the procedures provided for in Part XV'. Under Part XV, a State party to the LOSC may designate one of three compulsory procedures for settling a boundary dispute: (i) the International Tribunal for the Law of the Sea (ITLOS); 54 (ii) the ICJ $;{ }^{55}$ and (iii) where designations made by States do not match, or in a

53 See Maritime Delimitation in the Area between Greenland and Jan Mayen (Denmark v. Norway), Judgment, [1993] ICJ Rep 38, at p. 59, para 48 (hereinafter Jan Mayen Judgment).

54 See https://itlos.org; accessed 28 August 2018.

55 See https://icj-cij.org; accessed 28 August 2018. 
situation where no declaration has been filed, the default is to an ad hoc arbitral tribunal constituted in accordance with Annex VII of the LOSC.

Not having ratified the LOSC, Part XV has no application in the relationship between Canada and the United States. This means that Canada could not unilaterally institute proceedings over the Beaufort Sea dispute against the United States before any of the afore-mentioned tribunals without the consent of the United States. However, Canada could seek to conclude a special agreement with the United States whereby the two States agree to submit their dispute over the Beaufort Sea boundary to a mutually acceptable tribunal, with the treaty providing the jurisdiction of the tribunal and defining the question to be settled by it. However, it appears politically unlikely for the two countries to agree to have recourse to an international tribunal for resolution of their boundary issues.

Because the United States has not ratified the Losc, that treaty's legal regime for determining ECS rights of coastal States does not apply to the United States. The United States presumably is prevented from submitting scientific evidence to the CLCS, backing up its claim for an ECS in the Arctic waters of the Beaufort Sea, unless the CLCS decided to accept a submission by the United States at its discretion. The United States cannot arrogate to itself the power to declare an ECs and impose its outer limits on Canada. It is under a general international law obligation to negotiate in good faith with Canada over the two countries' ECs boundary. Such negotiations would see the two countries taking different positions than those regarding the boundary within $200 \mathrm{M}$. As this article will demonstrate, the strict equidistance method advocated by the United States does not favour it beyond $200 \mathrm{M}$. An adjudicated ECS boundary would require the two countries to conclude a special agreement whereby they submit the question of their ECs boundary to an international court or tribunal.

\section{Applicable Delimitation Law}

Whatever method for delimiting the Beaufort Sea boundary is applied or chosen, the Canada-United States boundary is to be determined in accordance with international law. ${ }^{56}$ The universally accepted listing of the sources of that

$5^{6}$ In the 2008 Ilulissat Declaration, the five circumpolar States (Canada, Denmark, Norway, Russia and the United States) that are member States of the Arctic Council confirmed that they 'remain committed to this legal framework [applicable to the Arctic Ocean] and to the orderly settlement of any possible overlapping claims' over areas of the Arctic Ocean and that any steps taken will be 'in accordance with international law'. Ilulissat Declaration, done at Ilulissat, Greenland, 28 May 2008, available at https:// arcticgovernance.org; accessed 26 August 2018. See also OR Young, 'The Arctic in Play: 
law is found in Article $38(1)$ of the ICJ Statute. ${ }^{57}$ The specific legal rules that might govern the determination of the Canada-United States boundary in the Beaufort Sea are subsumed under the rubric of Article 38(1)(a). They may be found in the particular agreements that may be or have been in effect between Canada and the United States, especially bilateral and multilateral treaties. ${ }^{58}$ For purposes of this article, we have assumed that there is no bilateral treaty binding on Canada and the United States that specifically and conclusively settles the maritime boundary separating the two States in the Beaufort Sea.

One also must examine rules of general application that form a substantial part of what is termed 'general international law'. These can be derived from the sources listed in Article 38 of the ICJ Statute, particularly multilateral treaties and customary international law, as evidenced by the practice of States. The general international law that is relevant in this context is the international law of the sea that applies to marine features. The classification of the Beaufort Sea as a sea properly so-called is beyond doubt: the Beaufort Sea is naturally connected to the oceanic waters of the world. As a maritime or oceanic sea, the international law of the sea is, of its own force, binding with regard to the Beaufort Sea.

The law of the sea is governed by a special treaty regime constituted by the Geneva Conventions concluded in 1958 and the LOSC for those States having signed and ratified them. Of the three relevant Geneva Conventions concluded in 1958, only the $\mathrm{CCS}^{59}$ is binding on both Canada and the United States. The Convention on the Territorial Sea and the Contiguous Zone ${ }^{60}$ has been signed and ratified by the United States, but Canada has only signed this treaty, meaning its provisions are not opposable to it in the relationship between

Governance in a Time of Rapid Change' (2009) 24(2) International Journal of Marine and Coastal Law 423 .

57 Article 38(1) stipulates that the sources to be applied by the ICJ shall be the following: (a) International conventions, whether general or particular, establishing rules expressly recognized by the contesting States; (b) International custom, as evidence of a general practice accepted as law; (c) The general principles of law recognized by civilized nations'. Article 38(1) also provides that '[s] ubject to the provisions of Article 59, judicial decisions and the teachings of the most highly qualified publicists of the various nations, [are to be applied] as subsidiary means for the determination of rules of law'.

$5^{8}$ Article 2(1)(a) of the Vienna Convention on the Law of Treaties (Vienna, 23 May 1969, in force 27 January 1980, 1155 UNTS 331), which reflects customary international law in many respects, defines a treaty as 'an international agreement concluded between States in written form and governed by international law, whether embodied in a single instrument or in two or more related instruments and whatever its particular designation'.

59 Convention on the Continental Shelf $\left(\mathrm{n}_{5}\right)$.

6o Convention on the Territorial Sea and the Contiguous Zone (Geneva, 29 April 1958, in force 10 September 1964) 516 UNTS 205 . 
Canada and the United States. The same applies to the Convention on the High Seas, ${ }^{61}$ which has been signed and ratified by Canada, but the United States has only signed it and hence is not bound by its provisions.

Even though the international law of the sea is applicable to the Beaufort Sea as an oceanic maritime feature and notwithstanding the fact that the LOSC is not, on its own force, applicable to the United States, some of the provisions of the LOSC have passed into customary international law and have acquired obligatory status as customary international law. This includes the delimitation principles included in Part II of the LOSC. Where the rules for delimiting the various zones of maritime jurisdiction described in the LOSC would result in the overlapping of the jurisdictional zones of States having adjacent or opposite coasts, the Convention provides that the territorial sea should be delimited by agreement, or failing agreement, by a theoretical median (equidistance) line. Exceptions are to be made for 'historic title or other special circumstances'.62 Under the LOSC, delimitation of EEZs and the continental shelf between States with adjacent or opposite coasts also is to be accomplished by agreement.

Notwithstanding their vagueness, the delimitation principles included in Part II of the LOSC, as applied and interpreted by international courts and tribunals, can serve as a useful starting point for future negotiation by Canada and the United States of the baselines for establishing the precise boundaries of the areas of sovereign jurisdiction within the presently undelimited areas of the Beaufort Sea. As noted above, the ICJ has held that the substantially identical delimitation provisions of Articles 74 and 83 of the LOSC reflect customary international law. ${ }^{63}$ As such, they could be considered to be binding on the United States as general international law and supplement the ccs. ${ }^{64}$

61 Convention on the High Seas (Geneva, 29 April 1958, in force 30 September 192) $45^{\circ}$ UNTS 11.

$62 \quad \operatorname{LosC}(\mathrm{n} 2)$, Article 15.

63 See Jan Mayen Judgment (n 53), at p. 59, para 48.

64 While the United States considers many of the provisions of the LOSC to constitute customary international law on the law of the sea and binding on it as such, it is unclear whether or not this applies to its delimitation provisions. See U.S. v. Alaska, $5^{\circ} 3$ U.S. 569, 588 n. 10 (1992) (citing Brief for United States, at 25, n. 6, stating that ' $[\mathrm{t}$ ] he United States has not ratified [LOSC], but has recognized that its baseline provisions reflect customary international law'.). See also NOAA (National Oceanic and Atmospheric Administration) Office of General Counsel statement on 'Law of the Sea Convention' ('Although not yet a party to the treaty, the U.S. nevertheless observes the UN LOSC as reflective of customary international law and practice'.), available at https://www.gc.noaa.gov/gcil_los.html; accessed 2 April 2018. 
While no clear or consistent set of rules can be perceived in this area, an international tribunal likely would apply, in addition to the ccs, customary international law of the sea rules to determine the rights and obligations of Canada and the United States with regard to their unresolved boundary in the Beaufort Sea. These would include, especially in a situation of natural resources straddling an international boundary, the general standards of comity, good faith and good neighbourliness in relationships between neighbouring States as well as the general rules of State responsibility for direct and indirect damage to the property and territory of a neighbouring State by reason of negligent or wilful conduct of the first State. While no hard-and-fast rules exist with regard to straddling deposits, the neighbouring States can be said to have an obligation to notify or consult each other upon discovery of such deposits, as well as an obligation to cooperate and to exercise mutual restraint. Even though contemporary international law does not recognise a duty to jointly develop or to unitise a cross-border reservoir, there is an affirmative duty to seek agreement toward cooperative exploitation of the straddling deposits. ${ }^{65}$

\section{Applicable Delimitation Methodology}

The rules and principles set forth in some 25 decisions rendered by various international courts and tribunals in maritime boundary cases since $1969^{66} \mathrm{can}$ be applied to a given disputed or unresolved boundary in order to make informed predictions regarding its outcome. The same applies to the controversy regarding the maritime boundary between Canada and the United States in the Beaufort Sea.

Certainty, equity and stability are key elements and integral parts of the delimitation process before an international court or tribunal. Reflecting these elements, an international court or tribunal charged with adjudicating the unresolved maritime boundary between Canada and the United States can be expected to employ the established three-stage approach in applying the equidistance/relevant circumstances methodology when fixing the boundary

65 As the ICJ held in a landmark decision rendered in 1969, "[a]nother factor to be taken into consideration in the delimitation of areas of continental shelf as between adjacent States is the unity of any deposits'. North Sea Continental Shelf Cases (Federal Republic of Germany/Denmark; Federal Republic of Germany/Netherlands), Judgment, [1969] ICJ Rep 3, at p. 51, para 97 .

66 While there are rulings by international tribunals that pre-date the February 1969 judgments of the ICJ in the North Sea Continental Shelf Cases and that are of certain relevance, the development of the international maritime delimitation jurisprudence can be said to have commenced in earnest in 1969 when the ICJ spelled out the relevant rules and principles applicable to the delimitation of maritime boundaries in its rulings rendered in parallel cases between Germany and Denmark and The Netherlands, respectively. 
in the Beaufort Sea ${ }^{67}$ Based on this approach and methodology, after identifying the relevant coasts with a view to determining the parties' overlapping claims and the relevant area within which the delimitation is to be effected and in which the projections of the parties' coasts overlap, a provisional delimitation line is established. In the majority of cases, this has been an equidistance line, drawn by reference to appropriate baselines. ${ }^{68}$ This constitutes Stage 1 of the maritime delimitation methodology.

In Stage 2 of the delimitation process, the provisionally constructed line is examined in the light of equitable factors, called 'relevant circumstances', so as to determine whether it is necessary to adjust or shift that line in order to achieve an equitable solution. As the ITLOS Special Chamber observed in the Atlantic Judgment, "[t]he overarching objective of maritime delimitation ... is to achieve an equitable solution'.69 The case law favours neutral factors of a geographical nature, ${ }^{70}$ such as a significant disparity between the length of the parties' coastlines within the area to be delimited, over area-specific factors such as oil concessions and oil activities. ${ }^{71}$ Physical seabed characteristics (geology) and socio-economic considerations are generally rejected as special/ relevant circumstances justifying the shifting or adjustment of the provisional delimitation line, at least within $200 \mathrm{M}$ for geophysical factors. ${ }^{72}$

Finally, and at Stage 3, an international tribunal will verify that the unadjusted or adjusted provisional line does not, as it stands, lead to an inequitable result by reason of a marked disproportion between the ratio of the respective coastal lengths and the ratio between the relevant maritime areas of each State by reference to the delimitation line. ${ }^{73}$ Thus, the ultimate delimitation involves

67 Atlantic Judgment (n 30), para 36o; Costa Rica v. Nicaragua Judgment (n 51), para 135.

68 According to the ITLOS Special Chamber, 'the international jurisprudence concerning the delimitation of maritime spaces in principle favours the equidistance/relevant circumstances methodology' and 'in the absence of any compelling reasons that make it impossible or inappropriate to draw a provisional equidistance line, the equidistance/ relevant circumstances methodology should be chosen for maritime delimitation'. Atlantic Judgment, ibid., para 289. As regards the three-stage approach, the jurisprudence reveals, with regard to the first stage, a greater or lesser departure from the line that would have been produced by a strict application of the equidistance method due to the treatment of the baselines or basepoints by a court or tribunal in a given case.

69 Ibid., para 409.

$70 \quad$ Ibid., para 453 .

71 Ibid., para 215 ('the proof of the existence of a maritime boundary requires more than the demonstration of longstanding oil practice or adjoining oil concession limits').

72 As regards fisheries and (drift) ice as relevant circumstances, see Jan Mayen Judgment (n 53 ), at p. 71, para 75 , and p. 73, para 78 , respectively.

73 See, e.g., Maritime Delimitation in the Black Sea (Romania v. Ukraine), Judgment, [20o9] ICJ Rep 61, at p. 103, para 122; Bangladesh/Myanmar Judgment (n 4), at p. 123, para 477; Atlantic Judgment (n 30), para 533 (referring to earlier jurisprudence). 
the application of a final proportionality check to verify the equitableness of the tentative delimitation and to ensure that the ultimate result is not tainted by some form of gross disproportion. The application of this 'disproportionality test' could result in an offshore island being given only 'half effect', or even no effect, in the delimitation. ${ }^{74}$

\section{Identifying the Relevant Area}

An international tribunal charged with delimiting a maritime boundary will commence the delimitation process by determining what is called the 'relevant area'. It does so by identifying the geographical context of the delimitation, including relevant coasts, protrusions and offshore features such as islands and shoals in the AOc. Disputing States often advance differing views on the extent of the relevant area. As the ITLOS Special Chamber pointed out in the Atlantic Judgment, "[f] or a coast to be considered relevant in maritime delimitation it must generate projections which overlap with those of the coast of another party.' ${ }^{75}$ With regard to the Beaufort Sea, the relevant area is represented by the overlapping coastal projections of Canada and the United States.

In the absence of claims formally submitted by both parties as part of international arbitral or judicial proceedings, the parties' positions regarding the disputed boundary and, hence, the relevant area within which a third-party delimitation is to be affected cannot be formulated with accuracy. This also applies to the Beaufort Sea. Hence, it is difficult to define the relevant coasts and relevant area in the present case. In such circumstances, outside experts or commentators are left to construe the parties' positions based on publicly available sources in an effort to simulate the important preliminary step that international courts and tribunals apply in fixing a maritime boundary in an area of overlapping claims. One also must take into account that the outer limits of the continental shelves of Canada and the United States have not been determined definitively. This means that it is only possible to give an approximation of the size of the relevant area in this case. Thus, the relevant area

74 See Atlantic Judgment (n 30), para 285 . The jurisprudence points to a shift in language towards a disproportionality test compared to the earlier use of proportionality concepts. Cf., e.g., Continental Shelf (Libyan Arab Jamahiriya/Malta), Judgment, [1985] ICJ Rep 13, at p. 53, para 74; Jan Mayen Judgment (n 53), at p. 67, para 66 with Atlantic Judgment (n 30), para 528 .

75 Atlantic Judgment, ibid., para 372. Taking into account the overall localised directions of coastal frontages and any relevant nearshore-foreshore smaller features such as islands, islets, sandbanks, reefs and rocks, major coastal sections were geographically computed by us, resulting in three prominent seaward coastal projections for Canada and one prominent seaward coastal projection for the United States. 
in the ECS is delimited by a line running from the relevant basepoint until it reaches the outer limits of the continental shelf of each of the two countries. ${ }^{76}$ For practical purposes, we have employed a random 400-M limit in construing the relevant area. The relevant area in this case covers approximately 400,000 square kilometres. The length of the relevant US coast is 323 kilometres and that of Canada is 1,063 kilometres.

\section{Applying the Three-Step Methodology}

Step 1: Fixing the Provisional Boundary in the Beaufort Sea

It has become the practice of international courts and tribunals charged with delineating boundaries to draw a single, 'multipurpose' boundary, that is, one uninterrupted boundary line delimiting the various zones of coincident jurisdiction appertaining to the disputing parties. ${ }^{77}$ In the case of the Beaufort Sea, these zones include the territorial sea, the EEz and the continental shelf within and beyond $200 \mathrm{M}$.

As stated above, in the majority of adjudicated boundary cases, a provisional delimitation line in the form of an equidistance line (for States with adjacent coasts) or a median line (for States with opposite coasts) is established by reference to appropriate basepoints or baselines, with basepoints not on the normal baselines typically being ignored by a court or tribunal. Thus, the next step in the delimitation process involves the selection of baselines for establishing the provisional equidistance line 'on the basis of the geographic particularities of the coast under consideration.' ${ }^{78}$

Fig. 4, which uses Landsat TM8 (scale 1: 375,00o) 15-meter ground resolution, shows the 1985 published (gazetted) Canadian straight baselines (connected lines) and also, for some portions along Canadian offshore islands, the interpreted low water lines (LWL), which are the normal baselines shown as dotted lines. The actual 'gazetted' Canadian straight baselines were used 'as-is' in this LOS-DTS, as they generally matched the available present-day imagery. The Canadian normal baselines were simply digitised using recent Landsat TM8

76 Cf. ibid., paras $382-385$. In line with the practice followed in the Atlantic Judgment, we computed the length of the relevant coastlines by taking the wvs data and removing those indentations that would normally be closed by straight baselines. Ibid., para 380.

77 See Delimitation of the Maritime Boundary in the Gulf of Maine Area (Canada/United States), Judgment, [1984] ICJ Rep 246, at p. 267, para 27 (hereinafter Gulf of Maine Judgment). Canada and the United States likely would not favour a single boundary for the Beaufort Sea given that, as we demonstrate in this article, 'each of their positions within 200 nautical miles would seem to favor the other party further out'. Byers (n 21), at p. 91.

78 Atlantic Judgment (n 30), para 393 (referring to earlier jurisprudence). 


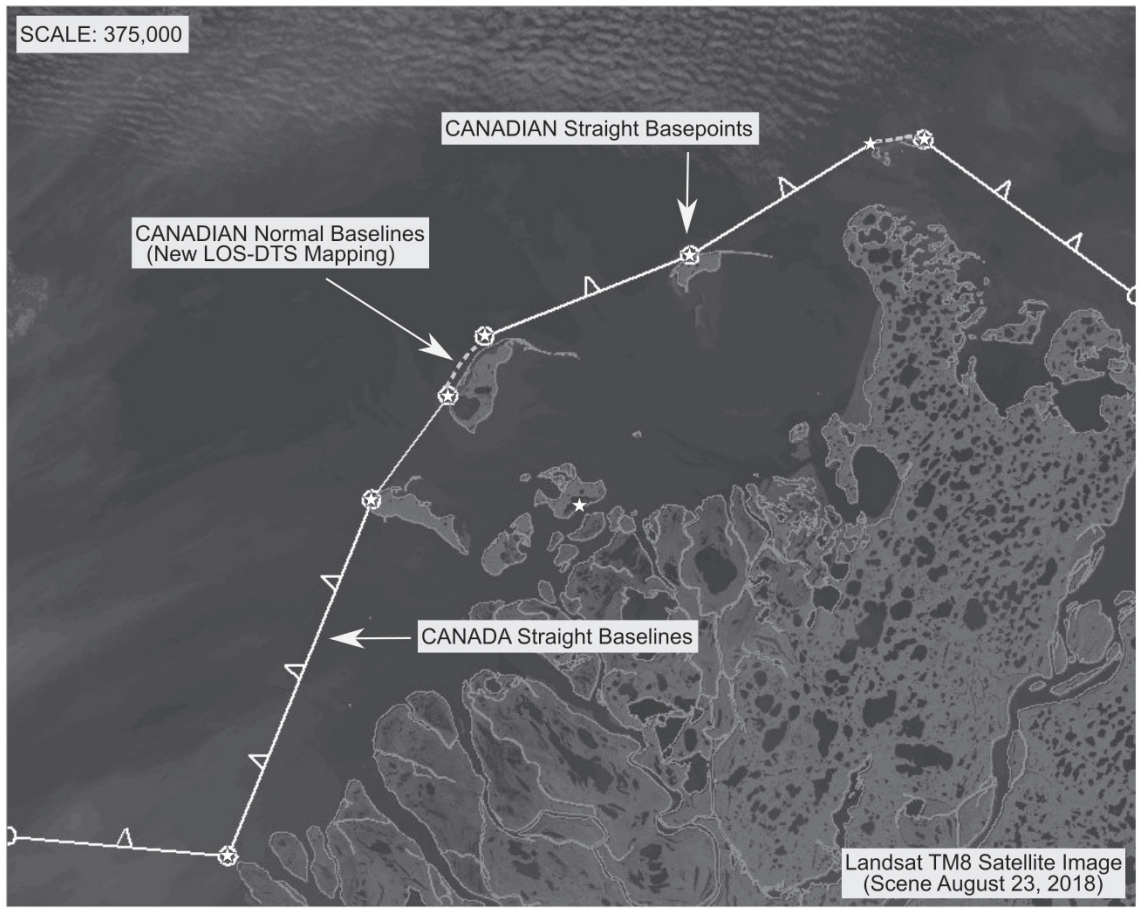

FIGURE 4 Gazetted straight and normal baselines of Canada

images. ${ }^{79}$ Ideally, both the straight and normal baselines should be updated for the United States and Canada, as positionally the 1985 mapped locations would not be as accurate when compared to the use of today's technology.

Fig. 5, which includes three inset images, each representing a 1:20,000 scale zoom-in, details 'old mapping versus new mapping' for one of many offshore fringing (barrier) islands situated in the vast stretch of US coastal waters along Alaska. All US (Alaskan) normal baselines used for all US LOS limit and boundary calculations result from present-day nautical charts produced by the National Oceanic and Atmospheric Administration (NOAA). The top-left image in Fig. 5 shows a group of islands (the Midway Islands) from nautical chart $16061 .{ }^{80}$ It appears that these waters were last surveyed between 1940 and 1951 .

79 Although Canada 'gazettes' where the coastal area 'will make use of Normal Baselines', it does not actually publish all the individual points. See Territorial Sea Geographical Coordinates (Area 7) Order, SOR/85-872, available at https://laws-lois.justice.gc.ca/eng/ regulations/SOR-85-872/FullText.html; accessed 19 July 2019 .

$80 \quad$ NOAA, published 1 January 2015 (1:50,ooo scale). 


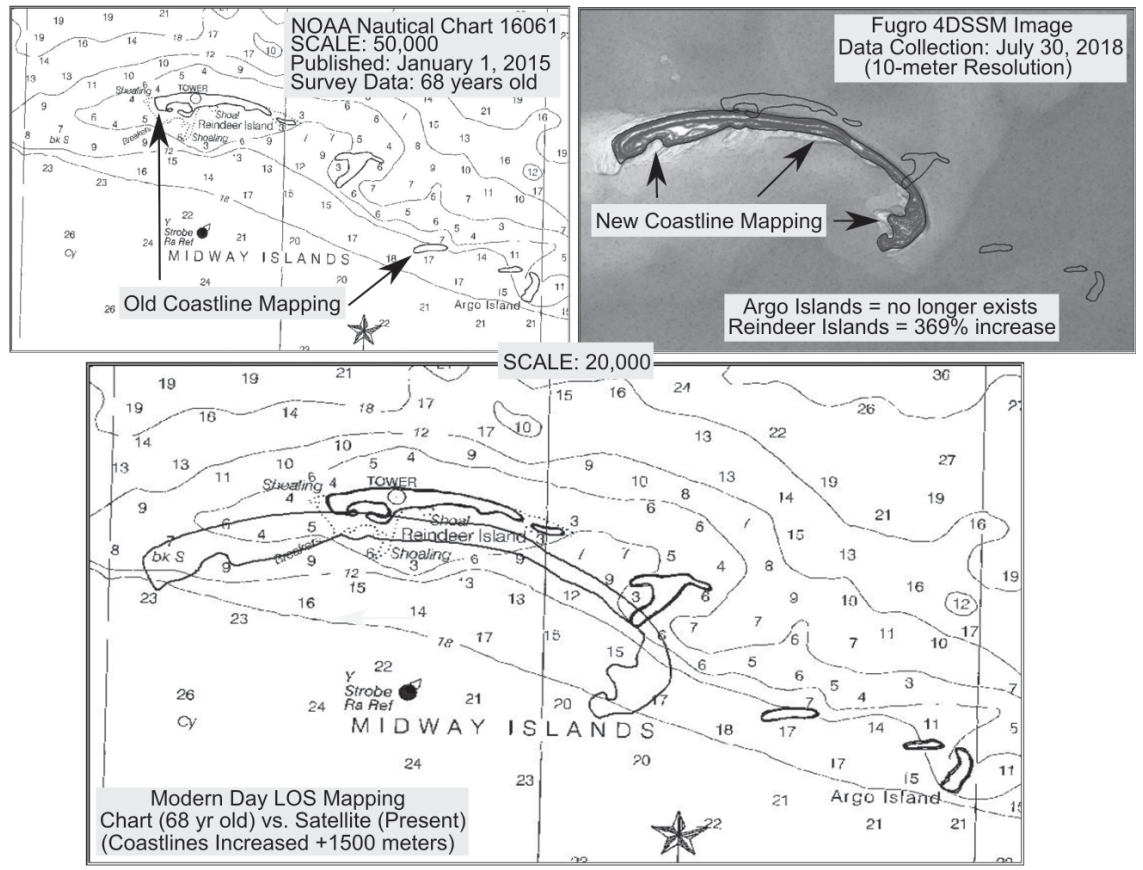

FIGURE 5 Midway Islands: Old mapping versus new mapping

The top-right inset in Fig. 5 is a 4 DSSM (satellite seafloor morphology) image from the Fugro Los database. ${ }^{81}$ This is a new technique used for remote mapping and shallow-water hazard mapping applications. It offers extremely useful present-day updated coastline interpretations and results, as well as nearshore-foreshore shallow-water seabed morphological feature information, such as sandbars, islets, reefs and rocks. This 4 DSSM image was additionally contoured in order to show the accurate interpreted 'outer edge of the island', that is, coastline. The bottom inset in Fig. 5 shows the results of how 67 to 78-year-old mapping compares to present-day mapping using this new 4DSSM

81 A new technique for $4 \mathrm{D}$ (i.e., $3 \mathrm{D}$ plus a time component possible, making $4 \mathrm{D}$ ) as Landsat TM8 imagery (15.0-metre ground resolution) is processed through a variety of proprietary customised tools and rendered in $3 \mathrm{D}$ in the Los-GIs for analysis. This new technique, created by Robert van de Poll as part of his Los projects, has been tested in more than $95^{\circ}$ projects worldwide. With very consistent results, he shows that this new SSM (satellite seafloor morphology), depending on source quality of imagery available, can 'see' seabed features to a maximum depth of 25 . o metres. This image is not showing bathymetry, but rather morphology of the seabed. In this example, the produced results were 'contoured' to accurately produce updated (interpreted) 2018 coastlines for the fringing (barrier) island. The source data in this specific example came from a Landsat TM8 image collected on 30 July 2018. 
technology. The sandy island has grown by 369 per cent and coastlines show improvements of up to 1,500 metres in this example. Present-day remapping of all of the US normal baselines by using this technique would dramatically improve all regional measurements for Los legal limits.

Fig. 2 above details the regional LOS-DTS area applying 'strict' equidistance line methodology from the Fugro database and using new updated (suggested) normal baselines for both the United States and Canada, where applicable. It is based on present-day analysis of regional coastlines using wvs and wvsII datasets, and then cross-referenced to all available nautical charts. Additionally, multiple modifications were made, using present-day Landsat TM8 satellite images. In some cases, advanced techniques of new 4DSSM image analysis were used to refine some US normal baselines. Ideally, this would be completed in survey-quality detail. All of this hierarchy of improved datasets was used in the LOS-DTS software to produce a suggested boundary line in the Beaufort Sea. This line was actually computed out to a limit of $400 \mathrm{M}$ by simply 'doubling' the 200-M EEz limit so as to cover future ECS waters as well.

This mathematically (geodetically) produced line starts from the LTP, represented by a white star in Fig. 6. This is to be considered as a 'hypothetical line', offered in our LOS-DTS as an unbiased present-day calculated result, employing recognised LOS-GIS software, and using the 'computed and interpreted' normal baselines for both the United States and Canada along coastlines and coastal frontages, together with the 'as-is' (gazetted) straight baselines for Canada along coastlines and coastal frontages to the east of the white star. For this LOS-DTS, an entire new line was produced. Although in close proximity in some locations to the United States' declared line, this line is seen to have discrepancies with the resulting computed line of up to 5,323 metres. This type of computed boundary line is based on the strict equidistance line principle. It is also useful to see how the geometry of the line dramatically changes as the line crosses the EEZ limit of $200 \mathrm{M}$ into the yet-to-be-claimed ECS waters. As the ECS claims of both the United States and Canada still have to be produced and formally submitted in final form, having this strict equidistance line (here computed to $400 \mathrm{M}$ for ease of reference) will help when considering what boundary line within the EEZ is most representative, as they have differing views regarding the position of that line.

Fig. 6 also details the LTP used by the United States and Canada as the starting point for the unresolved boundary between the two countries in the Beaufort Sea. The white star LTP is interpreted, in the LOS-GIS software, as it sits exactly on the 141st-degree meridian line reflected in the 1825 Treaty of St. Petersburg. As this is the most recent and highest-resolution image available 


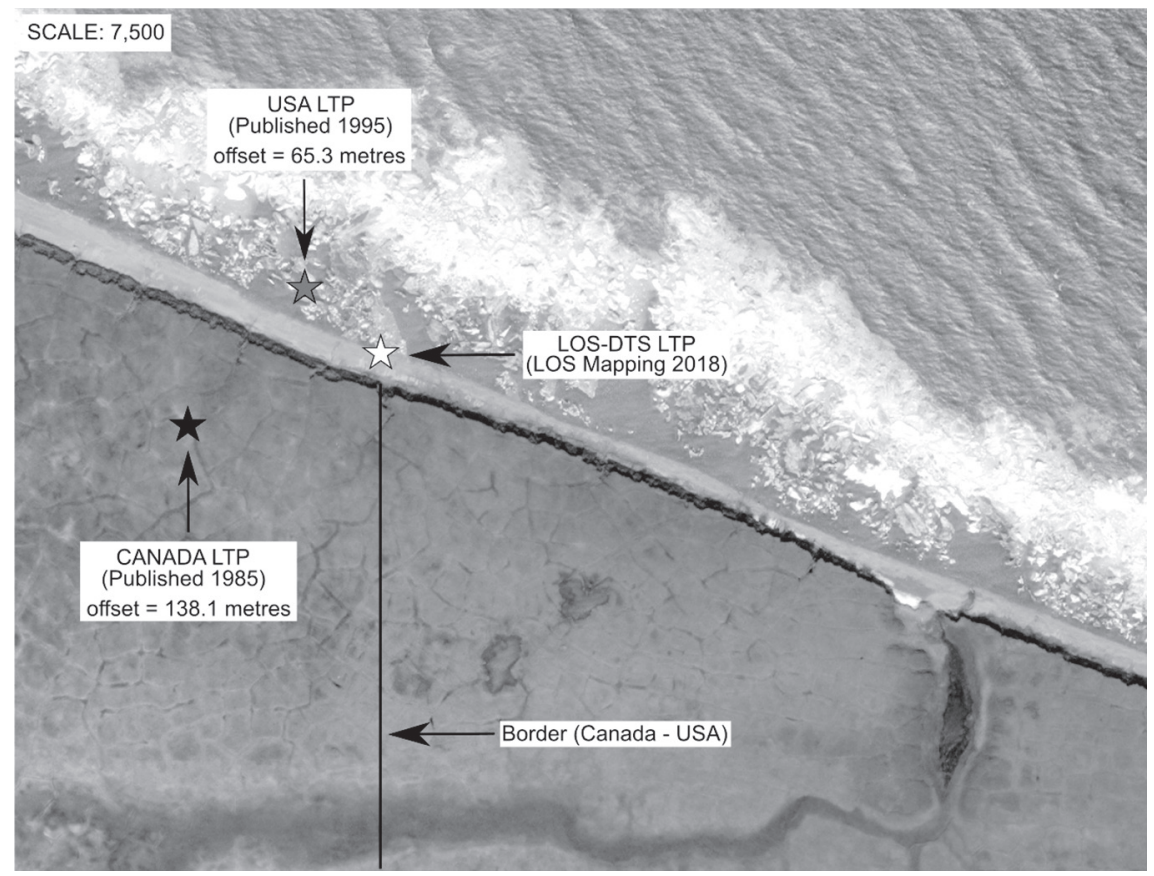

FIgURE 6 Land Terminus Point comparisons SOURCE: HTTPS://WWW.BING.COM/MAPS/AERIAL

(without actually putting 'boots on the ground' to conduct field surveys), the northing was interpreted at the land versus sea interface (i.e., the legal definition of the LTP, and the critical starting-point for analysis in this LOS-DTS), for the various scenarios for the boundary line. The black star in Fig. 6 denotes where Canada's official gazetted LTP sits, while the grey star shows where the United States' gazetted LTP is located based on detailed LOS-GIS analysis and importing the gazetted coordinates.

In line with established jurisprudence, any basepoints used for the construction of a provisional equidistance line in principle must be situated at the tidal low-water line, that is, on 'normal baselines'. ${ }^{82}$ Using CARIs-LOTS software, baselines can be identified for Canada and the United States in the Beaufort Sea. Fig. 7 below shows the relevant coastal frontages as follows: one large arrow for the United States, including the US тьвм (normal baselines), and three large light-shaded arrows for Canada, including the Canadian тsвм (normal and straight baselines).

$82 \quad$ Atlantic Judgment (n 30), para 396. See LOSC (n 2), Article 5. The LTP adopted by the IT LoS Special Chamber differs from the LTPs advanced by both parties. Ibid., paras 352-357. 


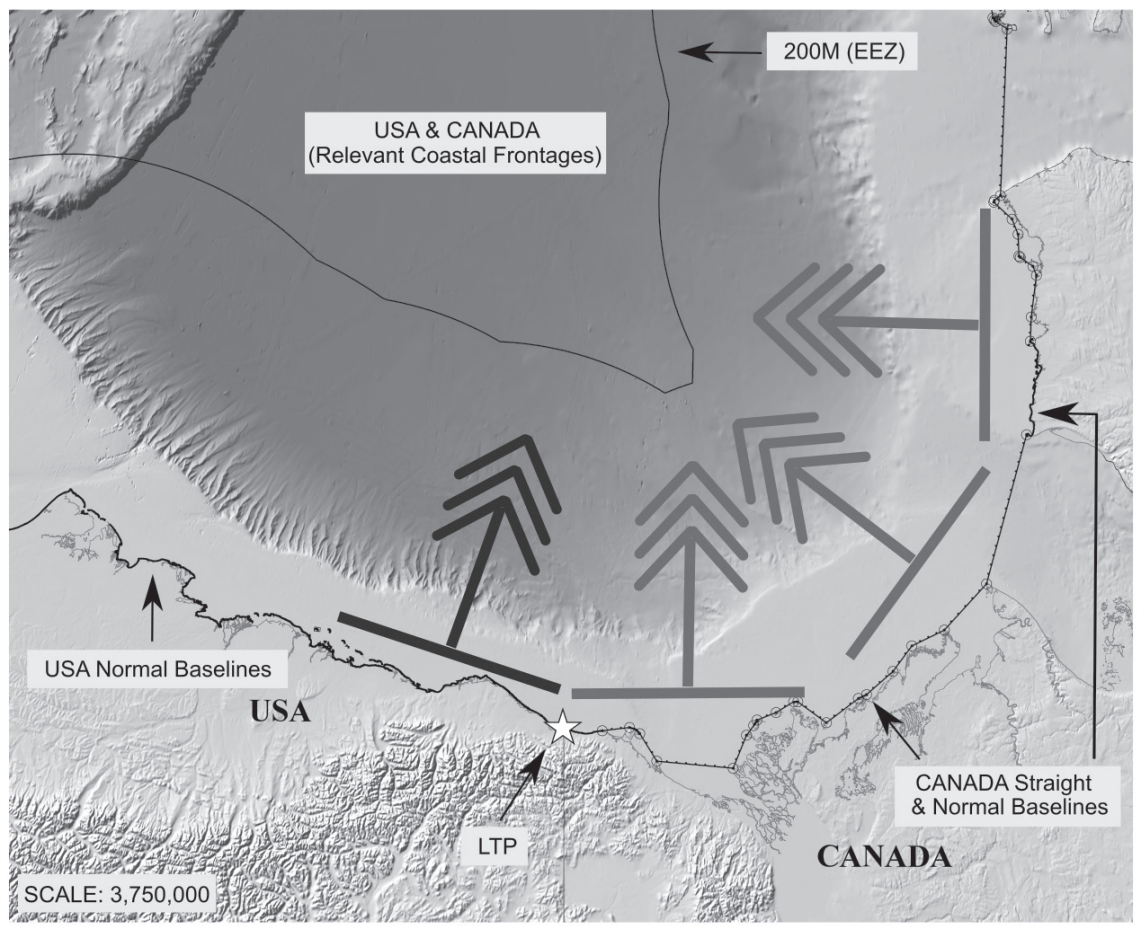

FIGURE 7 Relevant coastal projections for Canada and the United States

Fig. 7 details the regional LOS-DTS area for the United States versus Canada and the maritime frontier setting for the unresolved boundary in the Beaufort Sea and coastal projections used in defining the relevant area. The relevant US coastlines are shown, with the interpreted normal baselines, using combinations of the available NOAA nautical charts and more recent modernday Landsat TM8 satellite imagery. The relevant Canadian coastlines are also shown, with the gazetted straight baselines (straight lines along jagged/ irregular coastlines and crossing bays), together with some normal baselines along smooth coastal sections. These US and Canadian baselines were used to produce the (geodetic) 200-M E Ez legal limits (see black line well offshore) for the regional LOS-DTS area. The LTP, as interpreted for this LOS-DTS, is also shown in the form of a white star. It appears that there are no clear circumstances in this case dictating the use of a method other than equidistance/ relevant circumstances. ${ }^{83}$

83 Applying the bisector method could be appropriate in a case featuring a limited number of basepoints and their location on an unstable coastline that is not representative of the 


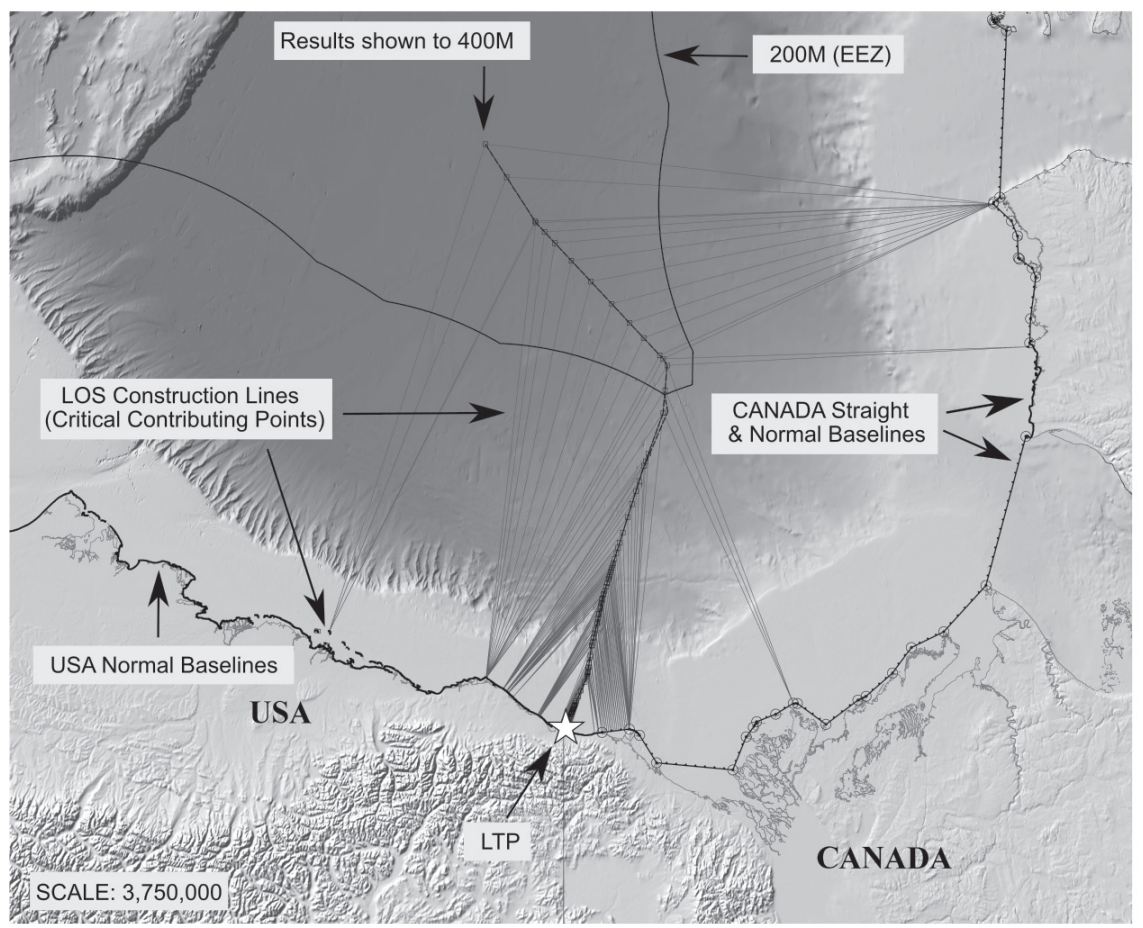

FIGURE 8 Beaufort Sea boundary based on 'strict' equidistance methodology

Having determined that delimitation of the area of overlapping claims could be satisfactorily accomplished by constructing a provisional equidistance line, we applied CARIS-LOTS to identify a starting point, represented by the land terminus resulting from the 1825 Treaty of St. Petersburg, and selected baselines for construction of the boundary line. CARIS-LOTS software for plotting boundaries customarily is applied by (parties before) international courts and tribunals in boundary cases. ${ }^{84}$ Fig. 8 shows the resulting boundary, which starts from the land terminus resulting from the 1825 Treaty of St. Petersburg and includes a number of turning points at which the direction of the line changes and which are connected by geodetic lines. From the northern-most turning point at $200 \mathrm{M}$ measured from the land terminus, the equidistance

overall coastal geography or where the maritime area off the relevant coasts is geographically complex, making it difficult to identify basepoints. However, it appears that these circumstances are not present in this case. It cannot be said that the relevant coasts of Canada and the United States are unstable, such that it is difficult or impossible to identify basepoints.

84 See, e.g., Atlantic Judgment (n 30), paras 389, 392. 
boundary continues as a geodetic line until it reaches the outer limits of the continental shelf beyond $200 \mathrm{M}$.

As regards the course of the line delimiting the continental shelf beyond $200 \mathrm{M}$, it was observed in the Atlantic Judgment that 'there is in law only a single continental shelf: ${ }^{85}$ Without fixing a termination point, this segment of the boundary can be said to run in a northwest direction from the line within $200 \mathrm{M}$ and continues in that direction until it reaches the outer limits of the continental shelf.

In the case of the unresolved Canada-United States boundary in the Beaufort Sea, a strict equidistance line would take the shape as indicated in Fig. 8. This figure shows the individual turning points (represented by square symbols connected together to create the suggested 'hypothetical' line), as tied back through construction lines, to the respective territorial sea baselines (basepoints) for both the United States and Canada. ${ }^{86}$

\section{Step 2: Determining the Presence of Relevant Circumstances}

Maritime boundary cases often involve, and are triggered by, competing claims to natural resources, and the case of the unresolved Beaufort Sea boundary is no different. International courts and tribunals have affirmed the cautious treatment that generally has been given to non-geographical, resource-related criteria when considering relevant circumstances that might justify adjusting or shifting a provisional equidistance line in cases where drawing such a line is feasible. As summarised by the ITLos Special Chamber in the Atlantic Judgment, 'international courts and tribunals have been consistent in their reluctance to consider oil concessions and oil activities as relevant circumstances justifying the adjustment of the provisional delimitation line'. ${ }^{87}$

With the possible exception of any pronounced concavity of coastlines on the Canadian side (in a situation where an international court or tribunal upholds a US challenge to Canada's use of straight baselines), we have been

85 Ibid., para 49o. See also ibid., paras 373, 526. The issues of continental shelf versus EEz delimitation and of delimitation within and beyond $200 \mathrm{M}$ are before the ICJ in a case pending at the time of writing. See Question of the Delimitation of the Continental Shelf between Nicaragua and Colombia beyond 200 nautical miles from the Nicaraguan Coast (Nicaragua v. Colombia), ICJ Case No. 154.

86 The geometry of these relevant coastal features was used to produce the suggested (geodetic) strict equidistance line in this LOs-DTs.

87 Atlantic Judgment (n 30), para 476. According to the ITLOS Special Chamber, 'a de facto line or modus vivendi related to oil practice cannot per se be a relevant circumstance in the delimitation of an all-purpose maritime boundary with respect to superjacent water as well as the seabed and subsoil'. Ibid., para 477 . 
unable to identify any argument that an adjustment or shifting of a provisional equidistance line would be required in the present case based on relevant circumstances. Strict application of the equidistance method would appear to result in an equitable solution in this case. The overarching objective of achieving an 'equitable solution' reflects the result dictated by the LOSC for boundaries in maritime areas lying beyond the territorial sea. We believe that the line constructed by us does not lead to an inequitable result owing to a marked disproportion between the ratio of the respective coastal lengths (here, 1:3.29 in favour of Canada) and the ratio of the relevant maritime area allocated to each party (here, 1:2.20 in favour of Canada). ${ }^{88}$

\section{Step 3: Applying a Final Disproportionality Check}

Taking into account all the circumstances of the case as we understand them based on publicly available information, we believe that the result achieved by the application of the delimitation line suggested in this article does not entail such disproportionality as to create an unequitable result. The size of the total area for the relevant waters has been calculated by us to be approximately 346,185 square kilometres (geodetic)..$^{89}$ The delimitation line produced by us allocates approximately 237,865 square kilometres (geodetic) to Canada and 108,320 square kilometres (geodetic) to the United States. The ratio of the allocated maritime areas is approximately 1:2.20 in favour of Canada. Based on the maritime delimitation jurisprudence, this ratio does not lead to any significant disproportion in the allocation of maritime areas to the two countries relative to the respective lengths of their relevant coasts. ${ }^{90}$

88 The jurisprudence indicates that a ratio of around 1:9 would justify modification, but lower ratios also have resulted in modified (segments of) median lines. Cf. Jan Mayen Judgment (n 53), at p. 65, para 61 (ratio of 1:9.1); Gulf of Maine Judgment (n 77), at p. 336, para 222 (ratio of 1:1.38). We note that, in any case involving concavity of relevant coasts, an international tribunal would consider whether an equidistance line drawn between two coastal States produces a cut-off effect on the maritime entitlement of one of those States, necessitating an adjustment of that line. See Atlantic Judgment (n 30), para 421. In cases where concavity is not very pronounced, and any cut-off only comes into being at a considerable distance from the land boundary terminus (150 M or more), an adjustment of a provisional equidistance line is less likely. Ibid., para 424. We have not considered any possible cut-off effect in the present case.

89 The area that was calculated for this purpose was measured from the relevant coastal frontages of Canada and the United States to the 200-M limit.

9o A ratio of 1:2.02 was deemed insufficient to justify modification in a recent case. See Atlantic Judgment (n 30), paras 533, 536. 


\section{Agree-to-Disagree: Provisional Arrangements of a Practical Nature}

Pending final delimitation of an EEZ or continental shelf, or resolution of an undelimited boundary, States parties to the LOsC are required to 'make every effort to enter into provisional arrangements of a practical nature' in order to avoid conflict in an area of overlapping claims. ${ }^{91}$ It is unsettled whether this rule reflects customary international law and would be binding on the United States as such. There is no specific obligation under general international law to enter into a particular provisional arrangement, which may include joint development of mineral resources, cross-border unitization of mineral resources, the designation of special areas for fisheries purposes, and various forms of bilateral cooperation, such as coordinated patrolling.

The recent Atlantic Judgment is especially instructive regarding the legal obligations of neighbouring coastal States with active offshore oil blocks, but lacking an agreed boundary or a provisional arrangement for joint exploration and exploitation of hydrocarbons pending agreement on the common boundary. ${ }^{92}$ The rules and principles identified in that ruling can serve as a useful starting point for future negotiation by Canada and the United States of some kind of arrangement that would allow for the joint development of any straddling resources within the presently undelimited areas of the Beaufort Sea pending final delimitation of the Beaufort Sea boundary. ${ }^{93}$

\section{Conclusion}

This article has sought to demonstrate, by reference to 'best science' and 'best law', how an international court or tribunal with competent jurisdiction over the disagreement between Canada and the United States regarding their maritime boundary in Arctic waters in the Beaufort Sea would analyse the situation with a view to arriving at an adjudicated boundary that reflects an equitable result based on equitable principles. This situation, or at least its legal analysis, is complicated by reason of the fact that the two countries are not both parties to the LOSC, meaning that this treaty is not of its own force applicable to both Canada and the United States, and they have yet to publicise their full legal positions regarding the boundary in the Beaufort Sea. However, the delimitation

\footnotetext{
$91 \quad$ LOSC (n 2), Articles 74(3) and 83(3).

92 In the Atlantic Judgment ( $\mathrm{n} 30$ ), para 604, the ITLos Special Chamber emphasized that Article $83(1)$ of the LOSC imposes an obligation to negotiate in good faith, and that the exercise of good faith is especially relevant where neighbouring States are conducting maritime activities in close proximity to one another.

See also Byers (n 21), at pp. 88-89.
} 
rules and principles set forth in the LOSC can be considered to reflect customary international law binding on non-parties such as the United States, and there is a substantial body of case law interpreting and applying those rules and principles that can be relied on as authoritative statements.

If the equidistance method were to be applied to the Canada-United States boundary in the Beaufort Sea, ${ }^{94}$ it appears to support the US position regarding the boundary delimitation method applicable in the Beaufort Sea, except that the eventual strict equidistance line, including its starting-point (LTP), might deviate from the coordinates of the equidistance line favoured by the United States and might not favour it beyond 200 M. It remains to be seen whether, in applying this method and faced with all available proof submitted by the parties, an international tribunal would opt for a 'strict' equidistance line as opposed to a 'modified' equidistance line that takes into account relevant circumstances such as concavity of coastlines and the presence of offshore islands and other maritime features of a geographical nature.

In this case, we have been unable to identify any compelling reasons that make it impossible or inappropriate to draw a provisional equidistance line in the Beaufort Sea, taking into account the coastlines and offshore maritime features in the relevant area to be delimited based on available mapping and satellite imagery, including new techniques such as 4DSSM. Moreover, while we have not researched the situation 'on-the-ground' in the area of overlapping claims and do not have the benefit of the full positions of Canada and the United States with regard to their claimed boundary in the Beaufort Sea such as would emerge from international proceedings, we have been unable to identify any relevant circumstances of the kind identified in the international jurisprudence that would call for the adjustment or shifting of a provisional equidistance line in the Beaufort Sea. In particular, any oil concessions and oil activities could not be considered as relevant circumstances, and we have been unable to identify compelling evidence of a tacit agreement regarding a de facto line based on oil activities of the two countries. ${ }^{95}$ Finally, application of the disproportionality test does not dictate an outcome that is at variance with strict equidistance. In sum, a strict equidistance line would appear to be an equitable result in the Beaufort Sea and in line with both conventional and customary international law.

94 Atlantic Judgment (n 30), para 289.

95 Ibid., paras 198-227; para 215 ('oil practice, no matter how consistent it may be, cannot in itself establish the existence of a tacit agreement on a maritime boundary'); Territorial and Maritime Dispute between Nicaragua and Honduras in the Caribbean Sea (Nicaragua v. Honduras), Judgment, [2007] ICJ Rep 659, at p. 735, para 253; Continental Shelf Judgment (n 3 ) (de facto line used by both parties in prior grants of concessions). 
While the preferable method for resolving the 'managed disagreement' regarding the Beaufort Sea boundary would be for Canada and the United States to conclude a boundary agreement based on rules and methods established in the practice of States and international jurisprudence, ${ }^{96}$ they also could 'agree-to-disagree' on their Beaufort Sea boundary and resort to provisional arrangements of a practical nature, including through joint development of hydrocarbons in the area of overlapping claims in the Beaufort Sea. There is ample evidence from State practice, including more than 35 joint development arrangements of varying kinds, that such solutions can be beneficial to both States and foster optimum development of straddling deposits. Recent jurisprudence provides useful guidance regarding the applicable rules and principles in concluding such arrangements. ${ }^{97}$

In sum, there is no reason why the managed disagreement regarding the Canada-United States maritime boundary in the Beaufort Sea could not be resolved peacefully or could stand in the way of exploration and exploitation of the natural resources in the Beaufort Sea in a manner that is beneficial to the two countries and their peoples, including indigenous communities, while serving as a catalyst for the peaceful and equitable resolution of other Arctic boundaries that remain to be delimited. ${ }^{98}$

96 Concluding a boundary agreement based on a delimitation methodology applied by international courts and tribunals in recent decades would satisfy 'the principle of transparency and predictability'. Atlantic Judgment (n 30), para 289 .

97 Ibid., paras 596-634.

98 The views expressed herein are solely those of the authors. Errors are the authors' responsibility. The authors would like to acknowledge the research assistance of Ross Blackhall, a CMS Cameron McKenna Nabarro Olswang LLP trainee. This article is based on a paper that was presented by the authors at the Arctic Technology Conference held in Houston, Texas, $5^{-7}$ November 2018. That paper, which lacks footnotes, is available on the AтC-отс Web site, http://otcnet.org/arctic; accessed 8 November 2018. 